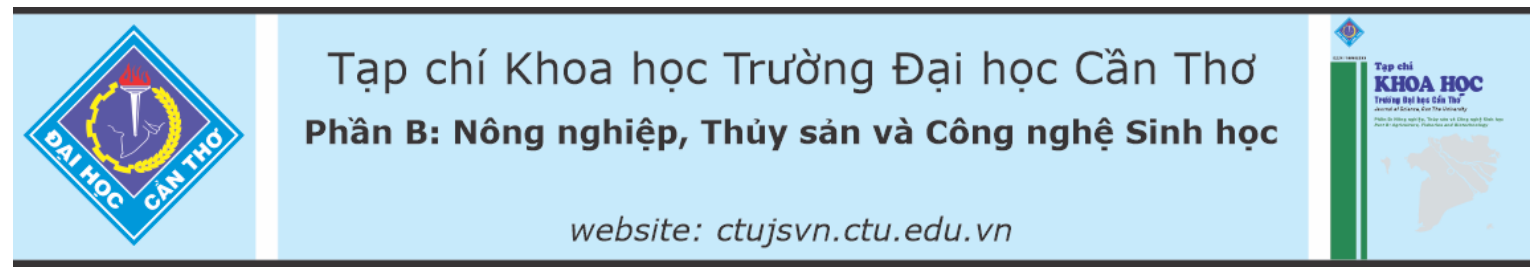

DOI:10.22144/ctu.jvn.2021.186

\title{
HIỆU QUẢ CỦA CHẾ PHẨM VI SINH CH!̣U MẬN NPISI LÊN SINH TRƯỞNG, NĂNG SUẤT LÚA VÀ ĐặC TÍNH ĐÂT NHIẼ̃M MặN MÔ HİNH TÔM-LÚA TẠI HUYỆN PHƯỚC LONG, TỈNH BẠC LIÊU
}

\author{
Nguyễn Hửu Thiện ${ }^{1}$, Nguyễn Hồng Giang ${ }^{2}$ và Nguyễn Khởi Nghĩa ${ }^{*}$ \\ ${ }^{1}$ Bộ môn Khoa học đất, Khoa Nông nghiệp, Truờng Đại học Cần Tho \\ ${ }^{2}$ Trung tâm Nghiên cứu Phát triển, Công ty cổ phần phân bón dầu khí Cà Mau \\ *Người chịu trách nhiệm bài viết: Nguyễn Khởi Nghĩa (email: nknghia@ctu.edu.vn)
}

\section{Thông tin chung:}

Ngày nhận bài: 06/06/2021

Ngày nhận bài sưa: 13/08/2021

Ngày duyệt đăng: 25/12/2021

Title:

Efficacy of NPISi salt tolerant microbial product on growth, yield of rice and salt effected soil properties in the shrimp rice farming system at Phuoc Long district, Bac Lieu province

\section{Tù khóa:}

Chế phẩm vi sinh chịu mặn NPISi, cố định đạm, đất nhiễm mạn, hòa tan lân, hòa tan Si, tồng hơp IAA

\section{Keywords:}

Dissolved phosphorus, dissolved silica, IAA synthesis, nitrogen fixing, NPISi salt tolerant microbial product, salt-affected soil

\begin{abstract}
The objective of the study was to evaluate the efficacy of NPISi salt tolerant microbial product containing several bacterial strains Bacillus aquimaris KG6-3, Burkholderia sp. BL1-10, Bacillus megaterium ST2-9 and Citrobacter freundii RTTV_12 on growth, yield of the Mot Bui Do rice cultivar and some salt affected soil characteristics in shrimp - rice farming system at Phuoc Long district, Bac Lieu province. The experiment was arranged in a completely randomized block design with 4 treatments and 4 replications. The results showed that the treatments applied with NPISi microbial product with a dose of $75 \mathrm{~kg} / \mathrm{ha}$ gave higher total concentrations of $S i, N, P$ and $K$ in rice stem and yield and were significantly different in statistics $(p<0.05)$ as compared with the control treatment applied only NPK fertilizer as farmer practice. In addition, the use of NPISi salt tolerant microbial product also helped to improve some chemical and biological properties of the salt affected soil through an increase of the content of available nitrogen, phosphorous, total bacterial numbers, nitrogen fixing, phosphate solubilizing, and silicate solubilizing bacterial numbers in soil at the end of the experiment.
\end{abstract}

\section{TÓM TẮT}

Mục tiêu của nghiên cứu là đánh giá hiệu quả của chế phẩm vi sinh chịu mặn NPISi chứa các dòng vi khuẩn Bacillus aquimaris KG6-3, Burkholderia sp. BL1-10, Bacillus megaterium ST2-9 và Citrobacter freundii RTTV_12 lên sinh truởng, năng suất giống lúa Một Bụi Đỏ và đặc tính đất nhiễm mặn trong mô hìn canh tác tôm-lúa ở huyện Phuớc Long, tỉnh Bạc Liêu. Thí nghiệm được bố trí thể thức khối hoàn toàn ngẫu nhiên gồm 4 nghiệm thức và 4 là̀n lặp lại. Kết quả nghiên cứu cho thấy các nghiệm thức có sủ dụng chế phầm vi sinh chịu mặn NPISi với liều luọng $75 \mathrm{~kg} / \mathrm{h}$ a cho hàm luợng Si tổng số, $N$ tổng số, $P$ tổng số, $K$ tổng số trong thân và năng suất lúa cao hơn và khác biệt ý nghĩa thống kê $(p<0,05)$ so với nghiệm thức đối chứng chỉ sủ dụng phân NPK theo kinh nghiệm của nông dân. Bên cạnh đó, việc sủ dụng chế phẩm vi sinh chịu mặn NPISi còn giúp cải thiện một số đặc tính hóa hoc và sinh hoc đất nhu hàm luợng đạm hưu dụng, P dễ tiêu, mật số vi khuẩn, mật số vi khuẩn cố định đạm, vi khuẩn hòa tan lân và vi khuẩn hòa tan Si trong đất ở thời điểm kết thúc thí nghiệm. 


\section{1. ĐẶT VẤN ĐỀ}

Đồng bằng sông Cửu Long (ĐBSCL) là một vùng trọng điểm cho phát triển kinh tế của cả nước và cung cấp lúa gạo cho cả nước với tổng diện tích trồng lúa khoảng 3,85 triệu ha, chiếm $80 \%$ diện tích đất sản xuất nông nghiệp của đồng bằng. Tuy nhiên, theo dự đoán của các cơ quan nghiên cứu về biến đổi khí hậu ở Việt Nam thì hiện tại có khoảng 1,7 triệu ha đất ở ĐBSCL (chiếm $42 \%$ tổng diện tích đất) bị ảnh hưởng bởi xâm nhập mặn do biến đổi khí hậu và nóng lên của toàn cầu (SIWRMP, 1995). Xâm nhập mặn là một trong những vần đề cấp thiết ảnh hưởng đến sản xuất nông nghiệp vì sự nhiễm mặn làm giảm sản lượng nông nghiệp một cách đáng kể (Corodovilla et al., 1994; Gisbert et al., 2000). Một trong những biện pháp thực tế nhằm giải quyết vấn đề ảnh hưởng của sự nhiễm mặn lên sự sinh trưởng và năng suất cây trồng đang được thế giới tập trung nghiên cứu đó là bổ sung (chủng) những vi khuẩn kháng mặn có khả năng sống trong vùng rễ cây trồng để kích thích sự phát triển của cây trồng và tăng năng suất trong điều kiện bất lợi từ tác nhân bên ngoài như sự xâm nhập mặn, khô hạn và thiếu dinh dưỡng (Venkateswarlu \& Shanker, 2009). Vi khuẩn vùng rễ kích thích sự tăng trưởng cây trồng (plant growth promoting rhizobacteria - PGPR) gồm những vi khuẩn khi chủng vào trong đất, chúng có khả năng sống tốt trong vùng rễ cây trồng và giúp cây trồng gia tăng sự sinh trưởng và phát triển. Hiệu quả của những vi khuẩn vùng rễ kích thích tăng trưởng cây trồng dưới điều kiện nhiễm mặn có liên quan đến độ dẫn điện trong nước, loại bỏ sự tích lũy những ion $\mathrm{Na}^{+}$, tăng sự bốc thoát hơi nước qua bề mặt lá và hoạt động quang hợp (Dodd \& PerezAlfocea, 2012), điển hình như vi khuẩn Azospirillum halopraeferens chịu đựng được $3 \% \mathrm{NaCl}$ (Reinhold et al., 1987), sống cố định trong rễ cây đước vùng nước mặn (Puente et al., 1999) và gia tăng sự phát triển của cây trồng chịu mặn khi tưới với nước biển (Bashan et al., 2000) hay vi khuẩn Gluconacetobacter diazotrophicus có khả năng cố định đạm và tiết ra các acid hữu cơ như oxalic, citric, gluconic... acids giúp hòa tan lân khó tiêu trong đất, bên cạnh đó, dòng vi khuẩn này còn có khả năng tiết ra phytohormone như IAA và gibberellin (Bastian et al., 1998).

Chế phẩm vi sinh chịu mặn NPISi có chứa 4 dòng vi khuẩn gồm vi khuẩn Bacillus aquimaris KG6-3 có chức năng cố định đạm, Burkholderia sp. BL1-10 có chức năng hòa tan lân, Bacillus megaterium ST2-9 tiết hormoon thực vật IAA (Nguyễn Khởi Nghĩa \& Nguyễn Thị Kiều Oanh,
2017) và Citrobacter freundii RTTV 12 giúp hòa tan Si khó tan trong đất (Trần Võ Hải Đường \& Nguyễn Khởi Nghĩa, 2018). Kết quả khảo sát đặc tính sinh lý của 4 dòng vi khuẩn trên cho thấy sự thích nghi của 4 dòng vi khuẩn này với các yếu tố môi trường bất lợi như: môi trường sống có độ mặn lên đến $3 \% \mathrm{NaCl}, \mathrm{pH}$ trong khoảng $5-9$, nhiệt độ $40^{\circ} \mathrm{C}$ và có khả năng gia tăng năng suất lúa trong điều kiện nhà lưới. Tuy nhiên, chưa có nghiên cứu đánh giá hiệu quả của chế phẩm vi sinh chịu mặn NPISi lên sinh trưởng, năng suất lúa và đặc tính đất nhiễm mặn trong mô hình canh tác lúa tôm ở điều kiện thực tế ngoài đồng. Do đó, việc ứng dụng chế phẩm vi sinh chịu mặn chứa các dòng vi khuẩn có tác dụng kích thích sinh trưởng và bảo vệ cây trồng trong điều kiện đất nhiễm mặn ở vùng ĐBSCL và biến đổi khí hậu diễn ra gay gắt như hiện nay là rất cần thiết. Vì vậy, nghiên cứu này được thực hiện nhằm mục tiêu đánh giá hiệu quả của chế phẩm vi sinh chịu mặn NPISi lên sinh trưởng, năng suất lúa Một Bụi Đỏ và một số đặc tính đất nhiễm mặn trong mô hình tôm-lúa tại huyện Phước Long, tỉnh Bạc Liêu.

\section{PHƯƠNG TIÊN VÀ PHƯƠNG PHÁP NGHIÊN CÚU}

\subsection{Phương tiện}

\subsubsection{Chế phẩm vi sinh NPISi}

Chế phẩm vi sinh NPISi chứa 4 dòng vi khuẩn có các chức năng sau: dòng Bacillus aquimaris KG6-3 có chức năng cố định đạm, dòng Burkholderia sp. BL1-10 có chức năng hòa tan lân, dòng Bacillus megaterium ST2-9 có chức tăng tổng hợp hoóc-môn thực vật IAA (Nguyễn Khởi Nghĩa \& Nguyễn Thị Kiều Oanh, 2017) và dòng Citrobacter freundii RTTV_12 giúp hòa tan Si khó tan trong đất (Trần Võ Hải Đường \& Nguyễn Khởi Nghĩa, 2018). Kết quả khảo sát đặc tính sinh lý của 4 dòng vi khuẩn trên cho thấy 4 dòng vi khuẩn này phát triển tốt và thực hiện chức năng của chúng trong môi trường nuôi cấy có độ mặn lên đến $3 \%$ $\mathrm{NaCl}, \mathrm{pH}$ trong khoảng 5-9, nhiệt độ $40^{\circ} \mathrm{C}$. Chế phẩm vi sinh chịu mặn dạng bột chứa bốn dòng vi khuẩn này được chuẩn bị tại Phòng thí nghiệm Vi sinh vật Đất, Bộ môn Khoa học Đất, Khoa Nông nghiệp, Trường Đại học Cần Thơ với mật số $10^{9}$ $\mathrm{CFU} / \mathrm{g}$ chế phẩm.

\subsubsection{Giống lúa}

Giống lúa Một Bụi Đỏ kháng mặn do Hợp tác xã Nông nghiệp Hồng Dân, xã Ninh Quới A, huyện Hồng Dân, tỉnh Bạc Liêu phối hợp với Viện Lúa ĐBSCL tuyển chọn được sử dụng trong nghiên cứu 
này. Lúa có chiều cao cây dao động từ 100 đến 135 $\mathrm{cm}$, trọng lượng 1.000 hạt khoảng 25,2 gram, hàm lượng protein $<8 \%$ và amylose $>25 \%$ (Lê Văn Tiến và ctv., 2011).

\subsection{Phương pháp nghiên cứu}

\subsubsection{Bố trí thí nghiệm}

Thí nghiệm được bố trí tại thị trấn Phước Long, huyện Phước Long, tỉnh Bạc Liêu trên nền đất nhiễm mặn trong mô hình canh tác lúa - tôm hơn 10 năm. Khu thí nghiệm có tổng diện tích là $480 \mathrm{~m}^{2}$ và được chia thành 16 lô có diện tích bằng nhau với diện tích $30 \mathrm{~m}^{2}\left(5 \mathrm{~m} \times 6 \mathrm{~m}=30 \mathrm{~m}^{2}\right)$. Các lô đất thí nghiệm được cách ly với nhau bằng các bờ xung quanh. Bên trong lô được cày xới và làm phẳng mặt ruộng trước khi sạ hạt giống. Mẫu đất trước khi phân các lô thí nghiệm được thu ở độ sâu $0-20 \mathrm{~cm}$ bằng cách thu ở nhiều vị trí khác nhau trên mặt ruộng khu thí nghiệm để phân tích một số đặc tính lý hóa và sinh học đất. Đặc tính đất đầu vụ được phân tích tại phòng thí nghiệm hóa lý và sinh học đất thuộc Bộ môn Khoa học Đất, Khoa Nông nghiệp, Trường Đại học Cần Thơ và kết quả phân tích một số đặc tính lý, hóa và sinh học đất đầu vụ được trình bày trong Bảng 1.

Thí nghiệm được bố trí vào vụ Thu Đông 2020 (9/2020-1/2021) theo thể thức khối hoàn toàn ngẫu nhiên gồm 4 nghiệm thức và 4 lần lặp lại, mỗi lô thí nghiệm tương ứng với 1 lặp lại. Các nghiệm thức được liệt kê như sau:

Nghiệm thức 1: Bón phân NPK theo nông dân $\left(43 \mathrm{~N}-68 \mathrm{P}_{2} \mathrm{O}_{5}-45 \mathrm{~K}_{2} \mathrm{O}\right)$.

Nghiệm thức 2: NPK theo nông dân + chế phẩm vi sinh chịu mặn NPISi $(75 \mathrm{~kg} / \mathrm{ha})$.

Nghiệm thức 3: NPK theo nông dân + phân hữu cơ (2 tấn/ha).

Nghiệm thức 4: NPK theo nông dân + chế phẩm vi sinh chịu mặn NPISi (75 kg/ha) + phân hữu cơ (2 tấn/ha).

Bảng 1. Đặc tính lý, hóa và sinh học đất đầu vụ tại thị trấn Phước Long, huyện Phước Long, tỉnh Bạc Liêu (9/2020)

\begin{tabular}{lrlr}
\hline Đặc tính đất & Kết quả & Đặc tính đất & Kết quả \\
\hline $\mathrm{pH}_{\mathrm{H} 2 \mathrm{O}}$ & 6,44 & Mật số nấm, $\left(\log _{10}(\mathrm{CFU} / \mathrm{g})\right)$ & 0 \\
$\mathrm{EC}$ bão hòa, $(\mathrm{mS} / \mathrm{cm})$ & 2,34 & Mật số xạ khuấn, $\left(\log _{10}(\mathrm{CFU} / \mathrm{g})\right)$ & 0 \\
$\mathrm{Chất} \mathrm{hữu} \mathrm{co,}(\%)$ & 4,43 & Mật số xạ khuâ̂n cố định đạm, $\left(\log _{10}(\mathrm{CFU} / \mathrm{g})\right.$ & 2,48 \\
$\mathrm{~N}_{\mathrm{ts}}(\% \mathrm{~N})$ & 0,18 & Mật số xạ khuẩn hòa tan lân, $\left(\log _{10}(\mathrm{CFU} / \mathrm{g})\right)$ & 2,78 \\
$\mathrm{NH}_{4}{ }^{+}-\mathrm{N},(\mathrm{mg} / \mathrm{kg})$ & 25,40 & Mật số vi khuẩn hòa tan silic, $\left(\log _{10}(\mathrm{CFU} / \mathrm{g})\right)$ & 0 \\
$\mathrm{NO}_{3}-\mathrm{N},(\mathrm{mg} / \mathrm{kg})$ & 0,42 & Dung trọng, $\left(\mathrm{g} / \mathrm{cm}^{3}\right)$ & 0,94 \\
$\left.\mathrm{P}_{\mathrm{ts}}, \% \mathrm{P}_{2} \mathrm{O}_{5}\right)$ & 0,05 & Độ xôp, $(\%)$ & 60,31 \\
$\mathrm{P}$ dễ tiêu, $(\mathrm{mg} / \mathrm{kg})$ & 4,18 & Thành phần cơ giới & Sét \\
$\mathrm{K}$ tổng, $\left(\% \mathrm{~K}_{2} \mathrm{O}\right)$ & 2,19 & $\%$ cát & 0,12 \\
$\mathrm{~K}$ trao đồi, $(\mathrm{meq} / 100 \mathrm{~g})$ & 1,97 & $\%$ thịt & 27,20 \\
Silic hòa tan $(\mathrm{g} / \mathrm{kg})$ & 14,51 & $\%$ sét & 72,68 \\
Mật số vi khuẩ,,$\left(\log _{10}(\mathrm{CFU} / \mathrm{g})\right)$ & 4,48 & & \\
\hline
\end{tabular}

Phân hữu cơ được sử dụng trong thí nghiệm là phân hữu cơ Sông Gianh có thành phần dinh dưỡng gồm $15 \%$ chất hữu cơ; $5 \% \mathrm{~N}_{\mathrm{ts}}, 2,5 \%$ humic acid, $1,5 \% \mathrm{P}_{2} \mathrm{O}_{5 \mathrm{hh}}, 2 \% \mathrm{~K}_{\mathrm{hh}}, 1 \% \mathrm{Ca}, 0,5 \% \mathrm{Mg}$ và $0,3 \% \mathrm{~S}$, một số nguyên tố vi lượng, nấm Aspergillus sp. $\left(10^{6}\right.$ $\mathrm{CFU} / \mathrm{g})$, vi khuẩn Azotobacter $\mathrm{sp}$. $\left(10^{6} \mathrm{CFU} / \mathrm{g}\right)$ và vi khuẩn Bacillus sp. $\left(10^{6} \mathrm{CFU} / \mathrm{g}\right)$ của Công ty Cổ phần Sông Gianh được nông dân canh tác lúa ở huyện Phước Long sử dụng phổ biến và được bón 1 lần vào thời điểm chuẩn bị đất. Mật độ gieo sạ với mức $40 \mathrm{~kg} / \mathrm{ha}$ và thực hiện công việc cấy tỉa và trồng dặm ở thời điểm 20 ngày sau sạ (NSS) (Trung tâm Khuyến nông tỉnh Bạc Liêu, 2017). Phân NPK được sử dụng trong thí nghiệm gồm phân urea $(46 \% \mathrm{~N})$ được sản xuất bởi Công ty Cổ phần Phân bón dầu khí Cà Mau, Kali Phú Mỹ $\left(60 \% \mathrm{~K}_{2} \mathrm{O}\right)$ và Super lân Long Thành $\left(16 \% \mathrm{P}_{2} \mathrm{O}_{5}\right)$ với công thức bón phân $43 \mathrm{~N}-68 \mathrm{P}_{2} \mathrm{O}_{5}-45 \mathrm{~K}_{2} \mathrm{O} \mathrm{kg} /$ ha và được chia làm 3 lần bón gồm 10 ngày, 20 và 70 NSS (Trung tâm Khuyến nông tỉnh Bạc Liêu, 2017). Chế phẩm vi sinh chịu mặn NPISi được chia làm 3 lần bón và được bón theo thời gian bón phân hóa học (không bón chung với phân hóa học) với tổng lượng bón là $75 \mathrm{~kg} / \mathrm{ha}$. Thông tin chi tiết về lượng phân bón cho từng thời điểm bón phân được trình bày trong Bảng 2 . 
Bảng 2. Lịch bón phân và lượng phân được bón trong thí nghiệm

\begin{tabular}{|c|c|c|}
\hline Thời điểm bón (ngày sau sạ) & Nghiệm thức & Lượng phân bón/lô thí nghiệm \\
\hline \multirow{4}{*}{$\begin{array}{l}\text { Chuẩn bị đất } \\
\text { (0 NSS) }\end{array}$} & NPK & 1275 g super lân \\
\hline & NPK + NPISi & 1275 g super lân \\
\hline & NPK + PHC & 6 kg PHC Sông Gianh + 1275 g super lân \\
\hline & $\mathrm{NPK}+\mathrm{NPISi}+\mathrm{PHC}$ & 6 kg PHC Sông Gianh $+1275 \mathrm{~g}$ super lân \\
\hline \multirow{4}{*}{$10 \mathrm{NSS}$} & NPK & $93,5 \mathrm{~g}$ urea $+75 \mathrm{~g} \mathrm{KCl}$ \\
\hline & NPK + NPISi & $93,5 \mathrm{~g}$ urea $+75 \mathrm{~g} \mathrm{KCl}+75 \mathrm{~g}$ NPISi \\
\hline & $\mathrm{NPK}+\mathrm{PHC}$ & $93,5 \mathrm{~g}$ urea $+75 \mathrm{~g} \mathrm{KCl}$ \\
\hline & $\mathrm{NPK}+\mathrm{NPISi}+\mathrm{PHC}$ & $93,5 \mathrm{~g}$ urea $+75 \mathrm{~g} \mathrm{KCl}+75 \mathrm{~g}$ NPISi \\
\hline \multirow{4}{*}{$20 \mathrm{NSS}$} & NPK & $93,5 \mathrm{~g}$ urea $+75 \mathrm{~g} \mathrm{KCl}$ \\
\hline & NPK + NPISi & $93,5 \mathrm{~g}$ urea $+75 \mathrm{~g} \mathrm{KCl}+75 \mathrm{~g}$ NPISi \\
\hline & $\mathrm{NPK}+\mathrm{PHC}$ & $93,5 \mathrm{~g}$ urea $+75 \mathrm{~g} \mathrm{KCl}$ \\
\hline & $\mathrm{NPK}+\mathrm{NPISi}+\mathrm{PHC}$ & $93,5 \mathrm{~g}$ urea $+75 \mathrm{~g} \mathrm{KCl}+75 \mathrm{~g}$ NPISi \\
\hline \multirow{4}{*}{70 NSS } & NPK & $93,5 \mathrm{~g}$ urea $+75 \mathrm{~g} \mathrm{KCl}$ \\
\hline & NPK + NPISi & $93,5 \mathrm{~g}$ urea $+75 \mathrm{~g} \mathrm{KCl}+75 \mathrm{~g}$ NPISi \\
\hline & $\mathrm{NPK}+\mathrm{PHC}$ & $93,5 \mathrm{~g}$ urea $+75 \mathrm{~g} \mathrm{KCl}$ \\
\hline & $\mathrm{NPK}+\mathrm{NPISi}+\mathrm{PHC}$ & $93,5 \mathrm{~g}$ urea $+75 \mathrm{~g} \mathrm{KCl}+75 \mathrm{~g}$ NPISi \\
\hline
\end{tabular}

*Ghi chú: NPK: bón phân NPK theo nông dân, NPISi: chế phẩm vi sinh chịu mặn, PHC: phân hũu co

Nước của từng ô thí nghiệm được quản lý theo phương pháp của nông dân bằng cách duy trì mực nước trên mặt ruộng ở mức $5-10 \mathrm{~cm}$, sau đó khi nước rút đến thời điểm mặt ruộng vừa khô, cấp nước ngập mặt ruộng trở lại, lặp lại quy trình đến giai đoạn thu hoạch. Cỏ dại được quản lý bằng phương pháp thủ công, riêng sâu bệnh hại trên lúa được quản lý bằng biện pháp IPM và hạn chế tối đa việc sử dụng thuốc bảo vệ thực vật hóa học.

\subsubsection{Các chỉ tiêu theo dõi}

(1) Chiều cao cây: Chọn ngẫu nhiên 5 cây trong khung $0,25 \mathrm{~m}^{2}$, đo từ mặt đất đến chóp lá cao nhất ở thời điểm 30 và 60 NSS (khi cây lúa chưa trổ bông) và đến chóp bông ở thời điểm thu hoạch.

(2) Số chồi: đếm tất cả các chồi trong khung sắt cố định có diện tích $0,25 \mathrm{~m}^{2}$ sau đó qui đổi sang 1 $\mathrm{m}^{2}$.

(3) Năng suất thực tế: Thu tổng khối lượng hạt/5 $\mathrm{m}^{2}$ và xác định ẩm độ hạt lúa tươi, sau đó qui đổi ra năng suất lúa (tấn/ha). Năng suất lúa được tính theo công thức sau: $\mathrm{W}_{\mathrm{a}}=\left[\mathrm{W}_{\mathrm{b}} \times 10.000\left(\mathrm{~m}^{2}\right) \times(100-\right.$ $\left.\left.\mathrm{H}_{\mathrm{b}}\right)\right] /\left[1.000 \times 5\left(\mathrm{~m}^{2}\right) \times\left(100-\mathrm{H}_{\mathrm{a}}\right)\right]$, trong đó với: $\mathrm{W}_{\mathrm{a}}$ là năng suất thực tế ở ẩm độ $\mathrm{H}_{\mathrm{a}}\left(\right.$ (tấn.ha $\left.{ }^{-1}\right), \mathrm{H}_{\mathrm{a}}$ là ẩm độ chuẩn $14 \%, \mathrm{~W}_{\mathrm{b}}$ : khối lượng lúa tươi thu từ $5 \mathrm{~m}^{2}$ $(\mathrm{kg}), \mathrm{H}_{\mathrm{b}}$ là ẩm độ của hạt lúa tươi.

(4) Hàm lượng Si hòa tan trong đất $\left(\mathrm{Si}(\mathrm{OH})_{4}\right)$ : Đất được thu ở độ sâu $0-20 \mathrm{~cm}$ ở 4 vị trí đều trong $30 \mathrm{~m}^{2}$, sau đó trộn đều thành 1 mẫu. Hàm lượng silic hòa tan trong đất được xác định theo phương pháp hiện màu với Molybdenum Blue trên máy đo quang phổ của Pereira et al. (2003). Cách thực hiện như sau: cho $10 \mathrm{~g}$ mẫu đất vào chai nhựa có thể tích 330 $\mathrm{mL}$. Tiếp theo cho vào chai nhựa $50 \mathrm{~mL} \mathrm{Na}_{2} \mathrm{CO}_{3}(10$ $\mathrm{g} / \mathrm{L})$ và $50 \mathrm{~mL} \mathrm{NH} \mathrm{NO}_{3}(16 \mathrm{~g} / \mathrm{L})$. Sau đó lắc 60 vòng/phút trong 1 giờ và để yên dung dịch trong 5 ngày. Tiếp theo, lấy ra $1 \mathrm{~mL}$ dung dịch trong phía trên cho vào ống ly tâm $50 \mathrm{~mL}$, sau đó xác định hàm lượng silic trong dung dịch bằng cách hút $1 \mathrm{~mL}$ dịch trong nằm bên trên cho vào ống ly tâm $50 \mathrm{~mL}$, sau đó thêm $2,5 \mathrm{~mL}$ ammonium acetate $20 \%$, lắc 5 giây, thêm $1 \mathrm{~mL}$ ammonium molybdate $0,3 \mathrm{M}$ lắc 5 giây. Để yên mẫu 1 phút cho ổn định, sau đó thêm $0,5 \mathrm{~mL}$ tartaric acid $20 \%$, vortex 5 giây, thêm $0,5 \mathrm{~mL}$ dung dịch khử (thành phần dung dịch khử gồm: $2,0 \mathrm{~g}$ $\mathrm{Na}_{2} \mathrm{SO}_{3} ; 0,4 \mathrm{~g}$ acid 1-amino-2 naptho-4-sulfonic; 25 $\mathrm{g} \mathrm{NaOHSO}_{3}$ và $250 \mathrm{~mL}$ nước khử khoáng), lắc 5 giây, sau đó để yên mẫu trong điều kiện nhiệt độ phòng thí nghiệm trong 60 phút và đo bằng máy đo quang phổ ở bước sóng $815 \mathrm{~nm}$.

(5) Hàm lượng Si trong thân lúa: Hàm lượng Si trong thân được xác định theo phương pháp của Wei-min et al. (2005). Cách thực hiện như sau: Thân và lá lúa được đem đi sấy khô ở nhiệt độ $70^{\circ} \mathrm{C}$ trong 48 giờ và được nghiền qua rây $0,5 \mathrm{~mm}$. Sau đó, mẫu được cân $0,1 \mathrm{~g}$ và cho vào ống ly tâm $50 \mathrm{~mL}$, tiếp theo cho vào ống ly tâm $3 \mathrm{~mL} \mathrm{NaOH} 50 \%$, tiệt trùng ướt ở $120^{\circ} \mathrm{C}$ trong 20 phút. Định mức mẫu đến thể tích $50 \mathrm{~mL}$ bằng nước cất khử khoáng và xác định hàm lượng $\mathrm{Si}$ trong dung dịch theo phương pháp Molybdenum Blue Colorimetry (Hallmark et al., 1982).

(6) Hàm lương $\mathrm{NH}_{4}^{+}$và $\mathrm{NO}_{3}^{-}$trong đất: Được trích bằng $\mathrm{KCl} 2 \mathrm{M}$, sau đó đo theo phương pháp so 
màu trên máy quang phổ ở bước sóng $650 \mathrm{~nm}$ (Otsuki \& Sekiguchi, 1983).

(7) Hàm lượng lân dễ tiêu trong đất: Được xác định bằng phương pháp Bray $2 \mathrm{NaHCO}_{3}$ ở $\mathrm{pH} 8,5$, đo theo phương pháp so màu trên máy quang phổ ở bước sóng $880 \mathrm{~nm}$ (Sims, 2000).

(8) Hàm lượng Kali trao đổi $\left(K_{t d t}\right)$ được trích với $\mathrm{BaCl}_{2} 0,1 \mathrm{M}$, sau đó đo trên máy hấp thu nguyên tử (Sumner \& Miller, 1996).

(9) Hàm luợng NPK tổng số trong thân lúa: Mẫu thân và lá lúa được xử lý theo phương pháp tương tự như mục xác định hàm lượng $\mathrm{Si}$ trong thân lúa (2.2.2.(3)). Vô cơ mẫu với $\mathrm{H}_{2} \mathrm{SO}_{4}$ đậm đặc và salicylic acid. Sau đó, $\mathrm{N}$ tổng được xác định bằng phương pháp chưng cất Kjeldahl, $\mathrm{P}$ tổng số được đo bằng cách so màu trên máy đo quang phổ và $K$ tổng số được đo trên máy hấp thu nguyên tử.

(10) Mật số vi sinh vật trong đất: Được xác định theo phương pháp của Pepper and Gerba (2004). Mẫu được trích bằng dung dịch buffer phosphate với tỉ lệ $1: 10$ (đất : buffer) trong 1 giờ ở 150 vòng/phút. Năm mươi $\mu \mathrm{L}$ dung dịch huyền phù được hút ở các nồng độ pha loãng trải lên lần lượt các môi trường Tryptone Soya Agar (TSA), Potato Dextrose Agar
(PDA), Starch Agar, Burk Agar, NBRIP Agar, SEA để xác định lần lượt gồm mật số vi khuẩn, nấm, xạ khuẩn, vi khuẩn cố định đạm, vi khuẩn hòa tan lân và vi khuẩn hòa tan $\mathrm{Si}$ trong đất (Mehta \& Nautiyal, 2001; Park el al., 2005; Wilson \& Knight, 1952). Mẫu được đặt trong tủ ủ $30^{\circ} \mathrm{C}$ để cho vi sinh vật phát triển và xác định mật số khuẩn lạc vi khuẩn phát triển trên từng loại môi trường khác nhau.

\subsubsection{Phân tích số liệu}

Số liệu thí nghiệm được xử lý trên phần mềm Excel và kiểm định thống kê $\mathrm{ANOVA}$, so sánh bằng phép thử Tukey bằng phần mềm Minitab 16.2.

\section{KẾT QUẢ VÀ THẢO LUẬN}

3.1. Hiệu quả của chế phẩm vi sinh chịu mặn NPISi lên sinh trưởng và năng suất lúa

\subsubsection{Hiệu quả của chế phẩm vi sinh NPISi lên sinh truơong lúa}

Kết quả khảo sát hiệu quả của chế phẩm vi sinh chịu mặn NPISi lên chiều cao cây và số chồi của cây lúa được trình bày trong Hình 1 . Nhìn chung, chiều cao cây lúa khác biệt không có ý nghĩa thống kê khi so sánh với nhau $(\mathrm{p}>0,05)$, trong khi đó số chồi $/ \mathrm{m}^{2}$ giữa các nghiệm thức thí nghiệm khác biệt ý nghĩa thống kê $(\mathrm{p}<0,05)$ ở hầu hết các thời điểm khảo sát.
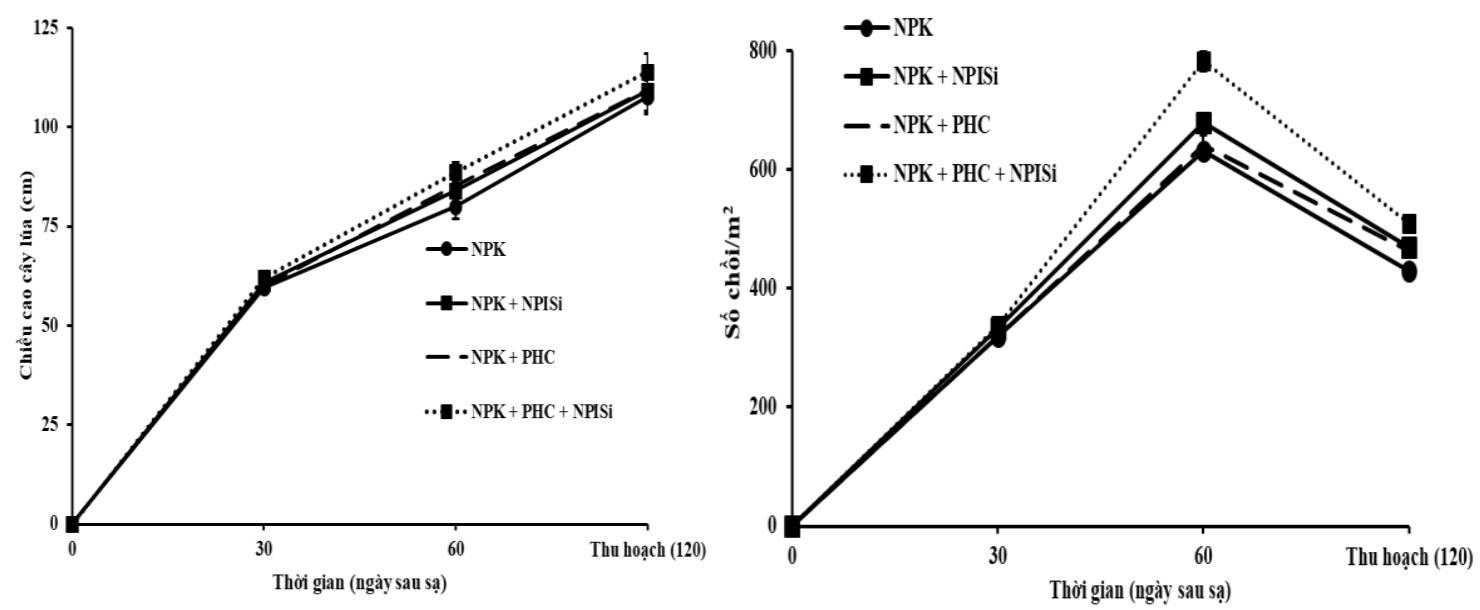

Hình 1. Chiều cao cây và số chồi lúa của các nghiệm thức thí nghiệm trên nền đất nhiễm mặn mô hình tôm-lúa tại huyện Phước Long, tỉnh Bạc Liêu (9/2020-1/2021)

Số chồi lúa/m² giữa các nghiệm thức thí nghiệm có sự khác biệt ở hầu hết các thời điểm khảo sát. Ở thời điểm 30 NSS, nghiệm thức bón NPK + NPSi và nghiệm thức bón NPK + PHC + NPISi có số chồi nhiều nhất, lần lượt là 334 chồi $/ \mathrm{m}^{2}$ và $337 \mathrm{chồi} / \mathrm{m}^{2}$ và khác biệt ý nghĩa thống kê $(\mathrm{p}<0,05)$ khi so sánh với 2 nghiệm thức không sử dụng chế phẩm vi sinh, tuy nhiên hai nghiệm thức này khác biệt không có ý nghĩa thống kê khi so sánh với nhau ( $\mathrm{p}>0,05)$. Đến thời điểm $60 \mathrm{NSS}$, nghiệm thức bón NPK + PHC + NPISi có số chồi nhiều nhất, 784 chồi $/ \mathrm{m}^{2}$ và khác biệt ý nghĩa thống kê $(\mathrm{p}<0,05)$ khi so sánh với tất cả các nghiệm thức còn lại. Nghiệm thức bón NPK + PHC và nghiệm thức bón NPK + NPISi có chiều cao cây cao thứ 2 và lần lượt đạt 651 và 679 chồi $/ \mathrm{m}^{2}$, 
trong khi đó nghiệm thức chỉ bón phân NPK theo nông dân có số chồi ít nhất, 631 chồi $/ \mathrm{m}^{2}$ và $\mathrm{xu}$ hướng này được duy trì đến thời điểm thu hoạch (120 NSS) và khi đó nghiệm thức bón NPK + PHC + NPISi có 510 chồi $/ \mathrm{m}^{2}$, cao nhất và khác biệt ý nghĩa thống kê so với các nghiệm thức còn lại $(\mathrm{p}<0,05)$. Nghiệm thức bón NPK + PHC (464 chồi $/ \mathrm{m}^{2}$ ) và nghiệm thức bón NPK + NPISi (470 chồi $/ \mathrm{m}^{2}$ ) có số chồi cao thứ 2 trong khi nghiệm thức chỉ bón NPK có số chồi đạt thấp nhất (430 chồi $\left./ \mathrm{m}^{2}\right)$. Do đó, có thể thấy việc sử dụng chế phẩm vi sinh chịu mặn NPISi giúp gia tăng số chồi lúa từ đó góp phần làm gia tăng năng suất lúa. Theo Yoshida (1981), số chồi có ảnh hưởng rất lớn đến năng suất lúa, vì số chồi ở các giai đoạn sinh trưởng ban đầu sẽ ảnh hưởng đến số bông lúc thu hoạch và số chồi thể hiện cho số bông cần thiết để tạo năng suất sau này.

\subsubsection{Năng suất lúa thực tế}

Kết quả đánh giá hiệu quả của chế phẩm vi sinh chịu mặn NPISi lên năng suất thực tế của lúa ở điều kiện ngoài đồng trên nền đất nhiễm mặn ở mô hình tôm-lúa tại huyện Phước Long, tỉnh Bạc Liêu được trình bày trong Hình 2 cho thấy năng suất thực tế của các nghiệm thức dao động từ 4,85 tấn/ha đến 5,47 tấn/ha và có sự khác biệt ý nghĩa thống kê ở mức ý nghĩa $5 \%(\mathrm{p}<0,05)$ Cụ thể, nghiệm thức chỉ bón phân NPK theo khuyến cáo $43 \mathrm{~N}-68 \mathrm{P}_{2} \mathrm{O}_{5-}$ $45 \mathrm{~K}_{2} \mathrm{O}$ có năng suất đạt 4,85 tấn/ha, thấp hơn và khác biệt ý nghĩa thống kê $(\mathrm{p}<0,05)$ khi so với hai nghiệm thức có sử dụng chế phẩm vi sinh chịu mặn NPISi gồm (1) nghiệm thức bón phân NPK kết hợp với $75 \mathrm{~kg} / \mathrm{ha}$ chế phẩm vi sinh chịu mặn NPISi và (2) nghiệm thức bón NPK + PHC + NPISi. Trong khi đó, nghiệm thức bón phân NPK theo kinh nghiệm của nông dân lại khác biệt không có ý nghĩa thống kê $(\mathrm{p}>0,05)$ khi so với nghiệm thức bón phân $\mathrm{NPK}+2$ tấn/ha phân hữu cơ $(4,91$ tấn/ha). Đồng thời, nghiệm thức bón NPK + PHC + NPISi cho năng suất cao nhất, đạt 5,47 tấn/ha và khác biệt ý nghĩa thống kê $(\mathrm{p}<0,05)$ khi so sánh với 3 nghiệm thức còn lại, bên cạnh đó còn giúp gia tăng $12,8 \%$ năng suất lúa so với nghiệm thức chỉ bón phân NPK theo nông dân.

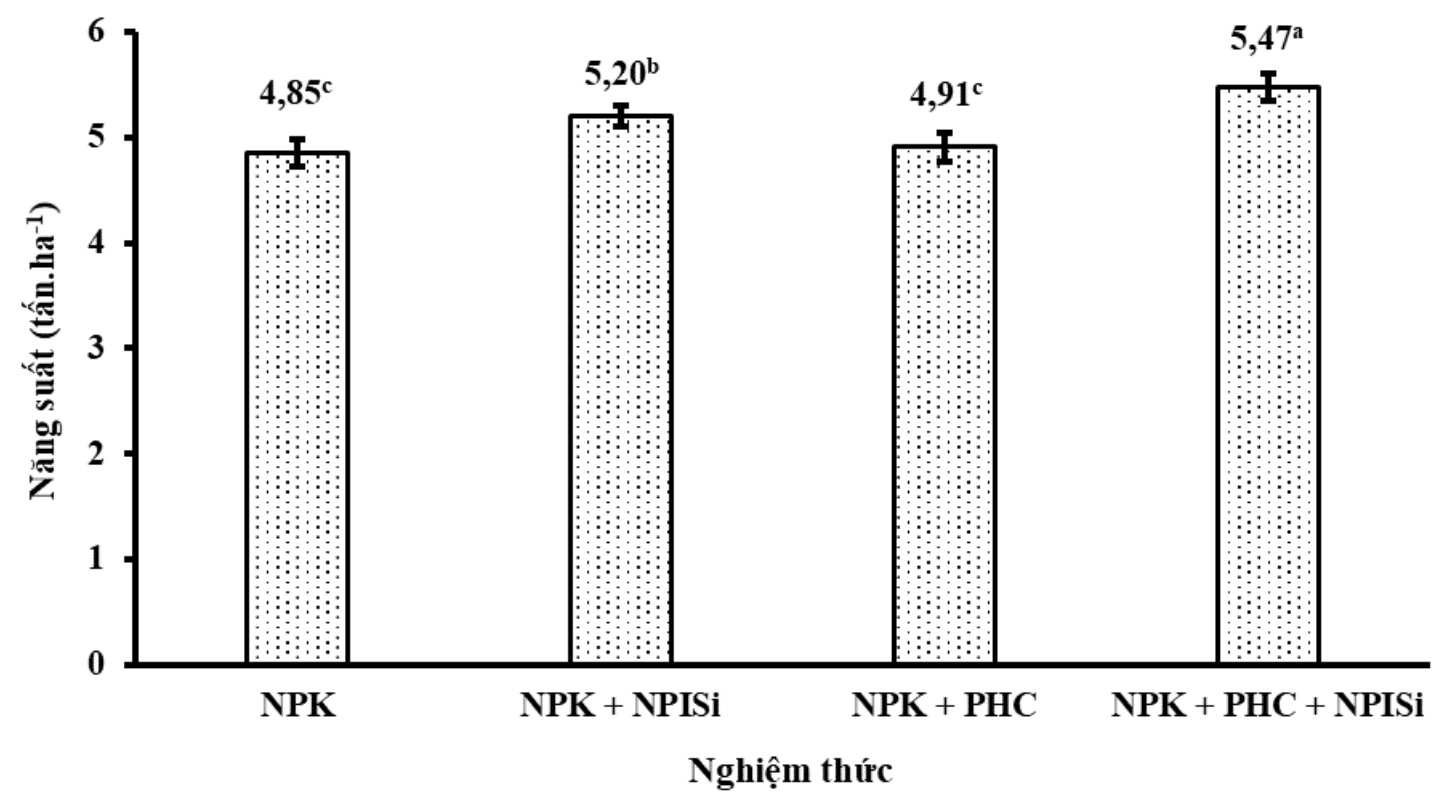

\section{Hình 2. Năng suất lúa thực tế của các nghiệm thức thí nghiệm trên nền đất nhiễm mặn mô hình tôm- lúa tại huyện Phước Long, tỉnh Bạc Liêu (01/2021)}

Nghiệm thức bón phân NPK kết hợp với 75 $\mathrm{kg} / \mathrm{ha}$ chế phẩm vi sinh NPISi có năng suất cao thứ hai với 5,20 tấn/ha, khác biệt ý nghĩa thống kê so với các nghiệm thức còn lại và giúp tăng $7,2 \%$ so với nghiệm thức đối chứng (chỉ bón phân NPK). Điều này có thể là do các dòng vi sinh vật có chức năng cố định đạm sinh học, hòa tan lân và hòa tan silic trong đất để tạo ra lượng đạm hữu dụng $\mathrm{NH}_{4}{ }^{+} / \mathrm{NO}_{3}{ }^{-}$, lân dễ tiêu và silic hòa tan giúp cây lúa hấp thu được nhiều dinh dưỡng hơn so với hai nghiệm thức không sử dụng chế phẩm vi sinh chịu mặn NPISi, từ đó giúp thúc đầy quá trình sinh trưởng, tăng số chồi, hình thành chất khô để tạo hạt góp phần gia tăng năng suất của cây lúa. Kết quả này 
tương tự như nghiên cứu của Lâm Thị Bạch Vân (2008) là việc chủng dòng vi khuẩn có chức năng cố định đạm Azospirillum lipoferum giúp thúc đẩy quá trình sinh trưởng, phát triển các thành phần năng suất lúa và gia tăng năng suất lúa trên nền đất phèn nhẹ hay nghiên cứu của Trần Võ Hải Đường và Nguyễn Khởi Nghĩa (2020) khi bón $100 \%$ NPK với công thức phân $43 \mathrm{~N}-68 \mathrm{P}_{2} \mathrm{O}_{5}-45 \mathrm{~K}_{2} \mathrm{O}+100 \mathrm{~kg} / \mathrm{ha}$ $\mathrm{CaSiO}_{3}+$ chế phẩm vi sinh chứa các dòng vi khuẩn có khả năng hòa tan Si giúp gia tăng năng suất của giống lúa Một Bụi Đỏ tại huyện Phước Long, tỉnh Bạc Liêu từ 5,06-15,5\%.

\subsection{Hiệu quả của chế phẩm vi sinh chịu mặn NPISi lên khả năng thu hút dinh dưỡng trong thân lúa}

\subsubsection{Hàm lượng Si trong thân lúa}

Kết quả phân tích hàm lượng Si trong thân lúa ở thời điểm thu hoạch được trình bày trong Hình 3 cho thấy có sự khác biệt thống kê $(\mathrm{p}<0,05)$ giữa các nghiệm thức thí nghiệm về hàm lượng Si trong thân lúa và dao động từ $22,2 \mathrm{~g} / \mathrm{kg}$ đến $24,5 \mathrm{~g} / \mathrm{kg}$.

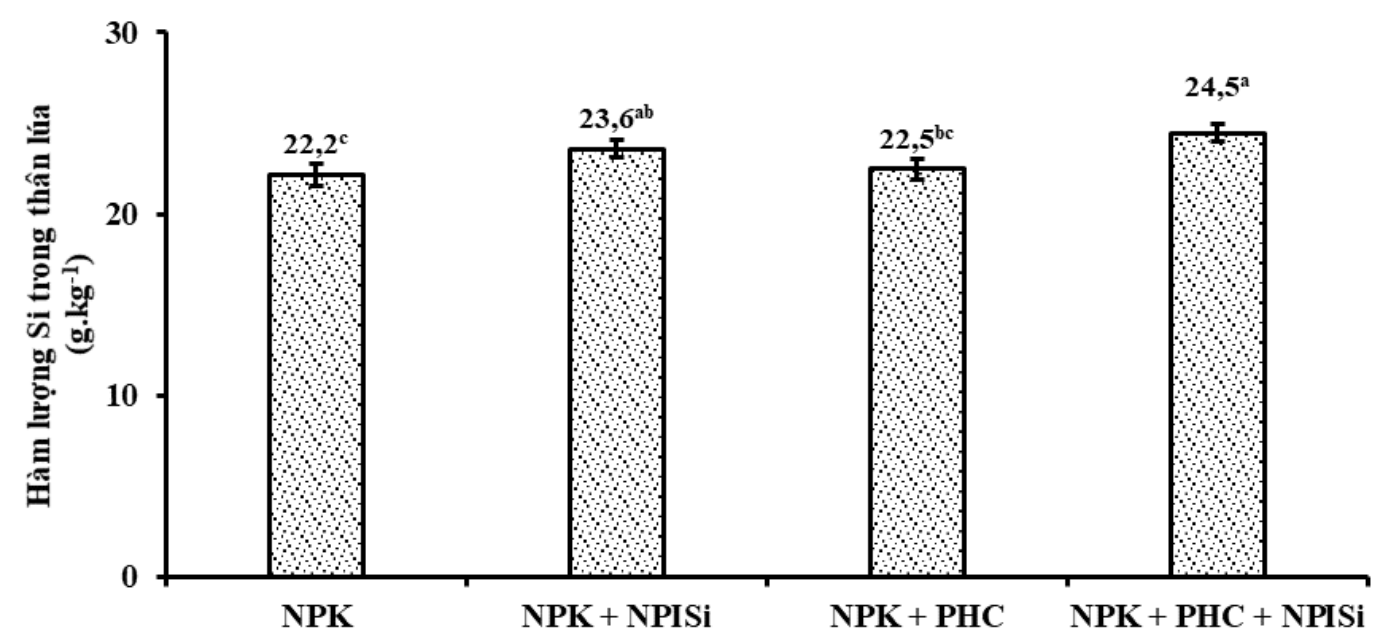

Nghiệm thức

\section{Hình 3. Hàm lượng Si trong thân lúa của các nghiệm thức thí nghiệm trên nền đất nhiễm mặn mô hình lúa tôm tại huyện Phước Long, tỉnh Bạc Liêu (01/2021)}

Có thể thấy, hai nghiệm thức có sử dụng chế phẩm vi sinh chịu mặn NPISi có hàm lượng Si trong thân lúa cao hơn khi so sánh với hai nghiệm thức không sử dụng chế phẩm vi sinh, trong đó nghiệm thức bón NPK + PHC +NPISi có hàm lượng Si trong thân cao và khác biệt ý nghĩa thống kê so với 2 nghiệm thức chỉ bón NPK và NPK+PHC ở mức $5 \%$ (p<0,05). Cụ thể, nghiệm thức bón phân NPK + phân hữu cơ + chế phẩm vi sinh chịu mặn NPISi có hàm lượng Si trong thân lúa đạt $24,5 \mathrm{~g} / \mathrm{kg}$, cao nhất và khác biệt ý nghĩa thống kê $(\mathrm{p}<0,05)$ so với hai nghiệm thức chỉ bón phân NPK và nghiệm thức bón phân NPK + phân hữu cơ. Cao thứ 2 là nghiệm thức bón phân NPK + NPISi với giá trị Si trong thân lúa đạt $23,6 \mathrm{~g} / \mathrm{kg}$, khác biệt ý nghĩa thống kê so với nghiệm thức chỉ bón phân NPK theo nông dân $(\mathrm{p}<0,05)$, tuy nhiên không khác biệt thống kê khi so sánh với nghiệm thức bón phân NPK + phân hữu cơ ( $p>0,05)$. Nghiệm thức chỉ bón NPK có hàm lượng Si trong thân thấp nhất với giá trị Si trong thân đạt
$22,2 \mathrm{~g} / \mathrm{kg}$. Bên cạnh đó, có thể thấy nghiệm thức bón phân NPK + PHC + NPISi giúp gia tăng hàm lượng Si trong thân lúa mặc dù không khác biệt ý nghĩa thống kê so với nghiệm thức bón NPK + phân hữu cơ có thể là do hiệu quả của dòng vi khuẩn Citrobacter freundii RTTV_12 có chức năng hòa tan $\mathrm{Si}$ khó tan trong đất thành dạng $\mathrm{Si}$ hòa tan $\left(\mathrm{H}_{4} \mathrm{SiO}_{4}\right)$, giúp cây lúa dễ dàng hấp thu vào thân thông qua việc hút nước từ rễ. Nghiên cứu của Rodrigues and Datnoff (2005) cho rằng $\mathrm{Si}$ chỉ được huy động dưới dạng hòa $\tan \left(\mathrm{H}_{4} \mathrm{SiO}_{4}\right)$ và được đưa vào trong tế bào biểu bì, mô cứng và bó mạch của thực vật, tiến trình hòa tan này chủ yếu được vi sinh vật trong đất thực hiện.

\subsubsection{Hàm luợng đạm, lân và kali tổng số trong thân lúa}

Kết quả phân tích hàm lượng đạm, lân và kali tổng số trong thân lúa của các nghiệm thức thí nghiệm được trình bày trong Bảng 3 cho thấy có sự 
khác biệt giữa các nghiệm thức về hàm lượng $\mathrm{N}$ tổng số, $\mathrm{P}$ tổng số và $\mathrm{K}$ tổng số.

Cụ thể, hàm lượng $\mathrm{N}$ tổng số của các nghiệm thức dao động từ 0,96-1,07\%. Nghiệm thức bón $\mathrm{NPK}+\mathrm{PHC}+\mathrm{NPISi}$ có hàm lượng $\mathrm{N}$ tổng số trong thân đạt cao nhất với giá trị 1,07\%, khác biệt ý nghĩa thống kê $(p<0,05)$ khi so với nghiệm thức chỉ bón NPK $(0,96 \%)$, tuy nhiên khác biệt không có ý nghĩa thống kê $(p>0,05)$ khi so với hai nghiệm thức còn lại NPK + NPISi $(1,05 \%)$ và NPK + PHC $(1,01 \%)$. Trong khi đó, nghiệm thức chỉ bón phân NPK có hàm lượng $\mathrm{N}$ tổng số đạt thấp nhất với $0,96 \%$, khác biệt ý nghĩa thống kê $(\mathrm{p}<0,05)$ so với hai nghiệm thức có sử dụng chế phẩm vi sinh NPISi, tuy nhiên khác biệt không có ý nghĩa thống kê $(p>0,05)$ khi so với nghiệm thức bón NPK + phân hữu cơ. Như vậy, kết quả này cho thấy hai nghiệm thức sử dụng chế phẩm vi sinh chịu mặn giúp cây lúa gia tăng hiệu quả hấp thu và huy động tốt hơn nguyên tố đạm lên trên thân lá lúa và giúp cho cây lúa xanh hơn, sinh trưởng và phát triển tốt hơn, dẫn đến năng suất lúa cũng cao hơn ở hai nghiệm thức này so với hai nghiệm thức còn lại.

Bảng 3: Hàm lượng đạm, lân và kali tổng số trong thân lúa của các nghiệm thức thí nghiệm trên nền đất nhiễm mặn mô hình tôm-lúa tại huyện Phước Long, tỉnh Bạc Liêu (01/2021)

\begin{tabular}{|c|c|c|c|}
\hline \multirow[b]{2}{*}{ Nghiệm thức } & \multicolumn{3}{|c|}{ Hàm lượng đạm, lân và kali tổng số trong thân lúa } \\
\hline & Đạm tổng số $(\% \mathbf{N})$ & Lân tồng số $\left(\% \mathrm{P}_{2} \mathrm{O}_{5}\right)$ & Kali tổng số $\left(\% \mathrm{~K}_{2} \mathrm{O}\right)$ \\
\hline NPK & $0,96^{\mathrm{b}}$ & $0,55^{\mathrm{b}}$ & $2,23^{\mathrm{d}}$ \\
\hline NPK + NPISi & $1,05^{\mathrm{a}}$ & $0,62^{\mathrm{a}}$ & $2,49^{\mathrm{c}}$ \\
\hline $\mathrm{NPK}+\mathrm{PHC}$ & $1,01^{\mathrm{ab}}$ & $0,64^{\mathrm{a}}$ & $2,57^{\mathrm{b}}$ \\
\hline $\mathrm{NPK}+\mathrm{PHC}+\mathrm{NPSi}$ & $1,07^{\mathrm{a}}$ & $0,64^{\mathrm{a}}$ & $2,73^{\mathrm{a}}$ \\
\hline $\mathrm{F}$ & $*$ & * & * \\
\hline $\mathrm{CV}(\%)$ & 4,66 & 7,66 & 7,41 \\
\hline
\end{tabular}

*Ghi chú: NPK: bón phân NPK theo công thức khuyến cáo; NPISi: chế phẩm vi sinh; PHC: phân hữu co; VK: vi khuẩn;

* là khác biệt ý nghĩa thống kê ở giũua các nghiệm thức ở mức ý nghĩa $5 \%$ theo phép thử Tukey và trong cùng một cột các số có chĩ theo sau giống nhau thì không khác biệt ý nghĩa thông kê ở 5\%

Kết quả này có được có thể là do trong chế phẩm vi sinh chịu mặn có chứa dòng vi khuẩn dòng Bacillus aquymaris KG6-3 có chức năng cố định đạm sinh học từ khí trời để tạo ra lượng đạm hữu dụng $\mathrm{NH}_{4}{ }^{+} / \mathrm{NO}_{3}$-trong đất ở hai nghiệm thức bón chế phẩm vi sinh này cao hơn, từ đó cây lúa hấp thu lượng đạm nhiều hơn so với hai nghiệm thức còn lại, giúp cây tạo sinh khối rễ và thân lá tốt hơn, chịu mặn tốt hơn, sinh trưởng tốt hơn và dẫn đến năng suất cao hơn, nhiều nghiên cứu đã chứng minh được điều này, điển hình như nghiên cứu của Nguyễn Ngọc Nga (2008) cho thấy việc sử dụng dòng vi khuẩn Azospirillum lipoferum có khả năng cố định đạm từ khí trời giúp tiết kiệm được $50 \% \mathrm{~N}$ và gia tăng năng suất cao gấp 1,75 lần so với đối chứng ở thí nghiệm ngoài đồng.

Hàm lượng $\mathrm{P}$ tổng số trong thân lúa dao động từ $0,55-0,64 \%$ và có sự khác biệt ý nghĩa thống kê $(\mathrm{p}<0,05)$ khi so sánh giữa các nghiệm thức với nhau. Cụ thể, hàm lượng $\mathrm{P}$ tổng số trong thân lúa ở nghiệm thức chỉ bón phân NPK đạt $0,55 \%$, thấp nhất và khác biệt ý nghĩa thống kê $(\mathrm{p}<0,05)$ khi so với các nghiệm thức còn lại. Trong khi đó, các nghiệm thức còn lại gồm nghiệm thức bón phân NPK + NPISi, nghiệm thức bón phân $\mathrm{NPK}+\mathrm{PHC}$ và nghiệm thức bón $\mathrm{NPK}+\mathrm{PHC}+\mathrm{NPISi}$ có hàm lượng $\mathrm{P}$ tổng số khác biệt không có ý nghĩa thống kê $(\mathrm{p}>0,05)$ khi so sánh với nhau và lần lượt là $0,62 \% ; 0,64 \%$ và $0,64 \%$. Như vậy, kết quả này cho thấy việc sử dụng chế phẩm vi sinh chịu mặn NPISi và phân hữu cơ Sông Gianh giúp cây lúa gia tăng hiệu quả hấp thu và huy động nguyên tố lân vào trong thân lúa từ đó giúp cây lúa khỏe hơn, chịu mặn tốt hơn, sinh trưởng tốt hơn và dẫn đến năng suất lúa cao hơn. Điều này có thể là do dòng vi khuẩn Burkholderia sp. BL1-10 trong chế phẩm vi sinh chịu mặn NPISi và một số chủng vi sinh trong phân bón hữu cơ sông Gianh có chức năng hòa tan lân, do đó, khi vào trong đất, dưới điều kiện đất nhiễm mặn có hàm lượng lân hữu dụng rất thấp $(4,18 \mathrm{mg} / \mathrm{kg})$ chúng hòa tan lân trong đất đề cho cây lúa hấp thu và huy động lân hiệu quả hơn và cao hơn. Nhiều nghiên cứu đã chứng minh rằng, các dòng vi sinh vật có khả năng giúp hòa tan lân khó tiêu trong đất thành dạng lân dễ tiêu, điển hình như nghiên cứu của Kundu and Guar (1984) cho thấy dòng vi khuẩn Pseudomonas sp. giúp giảm lượng phân lân bón vào đất từ $25-50 \%$.

Hàm lượng $\mathrm{K}$ tổng số trong thân lúa ở các nghiệm thức thí nghiệm dao động từ $2,23 \%$ đến 2,73\%. Nghiệm thức bón NPK + PHC+ NPISi có hàm lượng $\mathrm{K}$ tổng số cao nhất với giá trị $2,73 \%$. Nghiệm thức bón NPK + PHC có lượng kali tổng số 
cao thứ 2 (2,57\%), nghiệm thức bón NPK + NPISi cao thứ 3 với giá trị đạt $2,49 \%$ và nghiệm thức chỉ bón phân NPK có hàm lượng $\mathrm{K}$ tổng số thấp nhất $(2,23 \%)$. Đồng thời các nghiệm thức thí nghiệm có sự biệt ý nghĩa thống kê ở mức 5\% khi so sánh với nhau $(\mathrm{p}<0,05)$. Nhìn chung, việc bón phân hữu cơ sông Gianh hay chế phẩm vi sinh chịu mặn NPISi đơn lẻ đều giúp cây lúa gia tăng hiệu quả hấp thu và huy động nguyên tố kali vào trong sinh khối thân cây lúa, tuy nhiên, hiệu quả này được gia tăng hơn khi kết hợp cả hai (chế phẩm vi sinh chịu mặn NPISi, $75 \mathrm{~kg} / \mathrm{ha}$ và phân hữu cơ Sông Gianh, 2 tấn/ha). Việc cây lúa huy động lượng kali cao hơn trong sinh khối thân giúp cho cây lúa gia tăng sức chống chịu lại với các điều kiện bất lợi của môi trường như nhiễm mặn, khô hạn, sâu bệnh hại tấn công,... từ đó cây lúa sinh trưởng, phát triển tốt hơn, tạo sinh khối và năng suất lúa cao hơn. Như vậy, để có được kết quả này, chắc hẳn là trong phân hữu cơ Sông Gianh có thể có chứa một lượng kali hữu dụng rất đáng kể $(2 \%)$, do đó, cây lúa hấp thu thêm từ nguồn kali này dẫn đến hàm lượng kali tổng số trong thân lúa cao hơn nghiệm thức đối chứng chỉ bón phân NPK và nghiệm thức bón NPK + NPISi. Tuy nhiên, đối với nghiệm thức bón NPK + NPISi để có được kết quả kali tổng số trong thân lúa cao hơn nghiệm thức đối chứng thì ắt hẳn là trong chế phẩm vi sinh này có chứa dòng vi khuẩn nào đó có chức năng hòa tan kali tốt để phóng thích ra được lượng kali hữu dụng đáng kể trong đất để cây lúa hấp thu một cách hiệu quả. Tuy nhiên, chế phẩm vi sinh chịu mặn NPISi này không có chứa dòng vi khuẩn nào hòa tan kali, như vậy giả thuyết đặt ra có thể là hai dòng vi khuẩn hòa tan lân và hòa tan $\mathrm{Si}$ có khả năng có thêm chức năng hòa tan kali, tuy nhiên, cần phải được kiểm chứng giả thuyết này. Nhiều nghiên cứu đã chứng minh rằng có nhiều nhóm vi sinh vật có khả năng được kali trong khoáng đá vôi và đất, điển hình như nghiên cứu của Trần Thị Hồng Nhung (2010) cho thấy các dòng vi sinh vật gồm: Geobacillus spp., Bacillus spp., Sphingomonas spp. có thể hòa tan được kali có trong đất núi đá vôi ở Kiên Giang.

\subsection{Hiệu quả của chế phẩm vi sinh chịu mặn NPISi lên đặc tính đất cuối vụ thí nghiệm}

\subsubsection{Hàm lượng Si hòa tan trong đất}

Kết quả phân tích hàm lượng Si hòa tan trong đất trồng lúa tại thời điểm kết thúc thí nghiệm ở huyện Phước Long, tỉnh Bạc Liêu được trình bày trong Hình 4 cho thấy hàm lượng Si hòa tan trong đất dao động từ 40,2 - 47,2 $\mathrm{g} / \mathrm{kg}$ và có khác biệt ý nghĩa thống kê $(\mathrm{p}<0,05)$ khi so sánh giữa các nghiệm thức thí nghiệm với nhau.

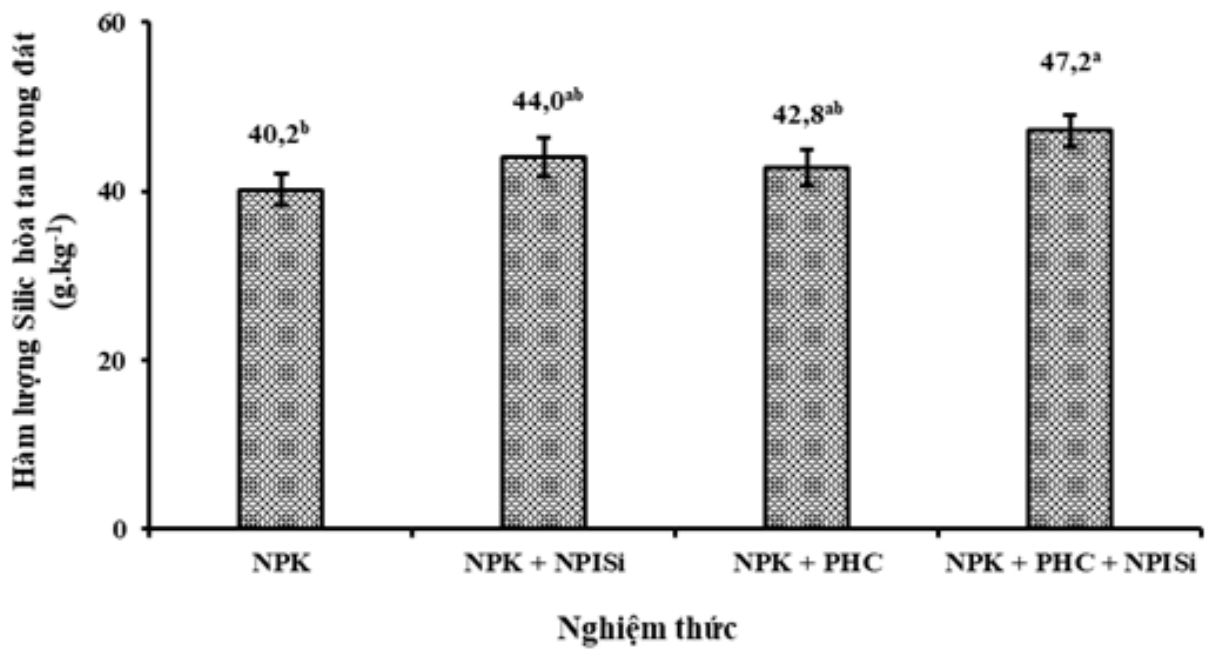

\section{Hình 4. Hàm lượng Si hòa tan trong đất của các nghiệm thức thí nghiệm trên nền đất nhiễm mặn mô hình tôm-lúa tại huyện Phước Long, tỉnh Bạc Liêu (01/2021)}

Nghiệm thức chỉ bón NPK có hàm lượng Si hòa tan thấp nhất với giá trị Si hòa tan đạt $40,2 \mathrm{~g} / \mathrm{kg}$, thấp hơn và khác biệt ý nghĩa thống kê $(\mathrm{p}<0,05)$ so với nghiệm thức bón NPK + PHC + NPISi $(47,2 \mathrm{~g} / \mathrm{kg})$, tuy nhiên, nghiệm thức này không khác biệt có ý nghĩa thống kê $(\mathrm{p}>0,05)$ khi so sánh với hai nghiệm thức còn lại (nghiệm thức bón NPK + NPISi (44,0 $\mathrm{g} / \mathrm{kg})$ và nghiệm thức bón $\mathrm{NPK}+\mathrm{PHC}(42,8 \mathrm{~g} / \mathrm{kg})$. Nghiệm thức bón NPK + PHC + NPISi có hàm lượng Si hòa tan cao nhất $(47,2 \mathrm{~g} / \mathrm{kg})$, khác biệt ý 
nghĩa thống kê $(\mathrm{p}<0,05)$ khi so sánh với nghiệm thức đối chứng (chỉ bón NPK), nhưng khác biệt không có ý nghĩa thống kê so với 2 nghiệm còn lại. Như vậy, kết quả này cho thấy việc bón chế phẩm vi sinh chịu mặn NPISi chứa dòng vi khuẩn hòa tan Si có xu hướng giúp gia tăng lượng $\mathrm{Si}$ hòa tan trong đất khi so sánh với nghệm thức chỉ bón NPK theo khuyến cáo, đặc biệt là ở nghiệm thức bón kết hợp NPK + PHC + NPISi. Kết quả này tương tự như nghiên cứu của Malinovskaya et al. (1990) và nghiên cứu của Trần Võ Hải Đường và Nguyễn Khởi Nghĩa (2020) cho thấy hiệu quả cao của vi khuẩn hòa tan $\mathrm{Si}$ trong việc hòa tan Si khó tan thành dạng hữu dụng cho cây trồng hấp thu.

\subsubsection{Hàm lượng $\mathrm{NH}_{4}{ }^{+}, \mathrm{NO}_{3}{ }^{-}, \mathrm{P}$ dễ tiêu và $\mathrm{K}$ trao đổi trong đất trồng lúa}

Kết quả phân tích hàm lượng $\mathrm{NH}_{4}{ }^{+}, \mathrm{NO}_{3}{ }^{-}, \mathrm{P}$ dễ tiêu và $\mathrm{K}$ trao đổi trong đất được trình bày trong Bảng 4. Nhìn chung, có sự khác biệt ý nghĩa thống kê $(\mathrm{p}<0,05)$ về hàm lượng $\mathrm{NH}_{4}{ }^{+}, \mathrm{NO}_{3}{ }^{-}$và $\mathrm{P}$ dễ tiêu trong mẫu đất cuối vụ thí nghiệm giữa các nghiệm thức khi so sánh với nhau, tuy nhiên, hàm lượng $\mathrm{K}$ trao đổi trong đất giữa các nghiệm thức khác biệt không có ý nghĩa thống kê ( $\mathrm{p}>0,05)$ khi so sánh với nhau.

Hàm lượng $\mathrm{NH}_{4}{ }^{+}$đạt cao nhất ở nghiệm thức bón $\mathrm{NPK}+\mathrm{PHC}+\mathrm{NPISi}$ với giá trị đạt $18,0 \mathrm{mg} / \mathrm{kg}$ đất và khác biệt ý nghĩa thống kê $(\mathrm{p}<0,05)$ klhi so sánh với ba nghiệm thức còn lại $(\mathrm{p}<0,05)$. Trong khi đó, nghiệm thức đối chứng chỉ bón NPK có hàm lượng $\mathrm{NH}_{4}{ }^{+}$thấp nhất (15,6 mg/kg đất). Nghiệm thức bón $\mathrm{NPK}+\mathrm{NPISi}$ cao thứ 2 với giá trị $\mathrm{NH}_{4}{ }^{+}$trong đất đạt $17,2 \mathrm{mg} / \mathrm{kg}$ đất và nghiệm thức bón $\mathrm{NPK}+\mathrm{PHC}$ đạt $16,2 \mathrm{mg} / \mathrm{kg}$ đất. Các nghiệm thức khác biệt ý nghĩa thống kê ở mức 5\% theo phép thử Tukey khi so sánh với nhau $(\mathrm{p}<0,05)$. Hàm lượng đạm $\mathrm{NH}_{4}{ }^{+}$ trong đất cuối vụ ở nghiệm thức bón phân NPK + PHC + NPISi cao hơn so với nghiệm thức bón NPK + NPISi có thể là do bản thân phân hữu cơ có chứa sẵn một lượng $\mathrm{NH}_{4}^{+}$.

Bảng 4. Hàm lượng $\mathrm{NH}_{4}^{+}, \mathrm{NO}_{3}^{-}, \mathrm{P}$ dễ tiêu và $\mathrm{K}$ trao đổi của các nghiệm thức thí nghiệm trên nền đất nhiễm mặn mô hình lúa tôm tại huyện Phước Long, tỉnh Bạc Liêu (01/2021)

\begin{tabular}{lrrrr}
\hline \multirow{2}{*}{ Nghiệm thức } & \multicolumn{4}{c}{ Hàm lượng $\mathbf{N H}_{4}^{+}, \mathbf{N O}_{3}^{-}, \mathbf{P}$ dễ tiêu và K trao đổi trong đất } \\
\cline { 2 - 5 } & $\begin{array}{r}\mathbf{N H}^{+} \\
(\mathbf{m g} / \mathbf{k g})\end{array}$ & $\begin{array}{r}\mathbf{N O}^{-} \\
(\mathbf{m g} / \mathbf{k g})\end{array}$ & $\begin{array}{r}\mathbf{P} \text { dễ tiêu } \\
(\mathbf{m g} / \mathbf{k g})\end{array}$ & $\begin{array}{r}\text { K trao đổi } \\
(\mathbf{m e q} / \mathbf{1 0 0} \mathbf{~ g r a m})\end{array}$ \\
\hline NPK & $15,6^{\mathrm{d}}$ & $0,43^{\mathrm{b}}$ & $5,02^{\mathrm{c}}$ & 1,97 \\
$\mathrm{NPK}+\mathrm{NPISi}$ & $17,2^{\mathrm{b}}$ & $0,84^{\mathrm{a}}$ & $5,13^{\mathrm{b}}$ & 1,97 \\
$\mathrm{NPK}+\mathrm{PHC}$ & $16,2^{\mathrm{c}}$ & $0,44^{\mathrm{b}}$ & $5,01^{\mathrm{c}}$ & 1,97 \\
$\mathrm{NPK}+\mathrm{PHC}+\mathrm{NPSi}$ & $18,0^{\mathrm{a}}$ & $0,85^{\mathrm{a}}$ & $5,46^{\mathrm{a}}$ & 1,99 \\
\hline $\mathrm{F}$ & $*$ & $*$ & $*$ & $\mathrm{~ns}$ \\
$\mathrm{CV}(\%)$ & 5,72 & 33,23 & 3,73 & 1,93 \\
\hline
\end{tabular}

*Ghi chú: NPK: bón phân NPK theo công thức khuyến cáo, NPISi: chế phẩm vi sinh, PHC: phân hũu co; VK: vi khuẩn,

* là khác biệt ý nghĩa thống kê ở giũa các nghiệm thức ở múc ý nghĩa 5\% theo phép thử Tukey và trong cùng một cột các số có chũ theo sau giống nhau thì không khác biệt ý nghĩa thống kê ở 5\%; ns: không khác biệt thống kê

Hàm lượng $\mathrm{NO}_{3}^{-}$trong mẫu đất cuối vụ thí nghiệm có sự khác biệt giữa các nghiệm thức có và không có sử dụng chế phẩm vi sinh chịu mặn NPISi. Cụ thể, nghiệm thức chỉ bón phân NPK và nghiệm thức bón NPK + PHC (2 tấn/ha) đạt lần lượt là 0,43 $\mathrm{mg} / \mathrm{kg}$ và $0,44 \mathrm{mg} / \mathrm{kg} \mathrm{NO}_{3}{ }^{-}$, thấp hơn và khác biệt ý nghĩa thống kê khi so với nghiệm thức bón phân $\mathrm{NPK}+\mathrm{NPISi}$ với $\left.0,84 \mathrm{~g} / \mathrm{kg} \mathrm{NO}_{3}^{-}\right)$và nghiệm thức bón phân NPK + PHC + NPISi $(0,85 \mathrm{mg} / \mathrm{kg})$.

Hàm lượng $\mathrm{P}$ dễ tiêu trong đất cuối vụ thí nghiệm cũng cho thấy có sự khác biệt ý nghĩa thống kê $(p<0,05)$ giữa các nghiệm thức có và không có sử dụng chế phẩm vi sinh chịu mặn NPISi. Cụ thể, nghiệm thức chỉ bón phân NPK và nghiệm thức bón phân NPK + PHC có hàm lượng $\mathrm{P}$ dễ tiêu lần lượt là $5,02 \mathrm{mg} / \mathrm{kg}$ và $5,01 \mathrm{mg} / \mathrm{kg}$, thấp hơn và khác biệt ý nghĩa thống kê $(\mathrm{p}<0,05)$ khi so sánh với nghiệm thức bón phân NPK + NPISi $(5,13 \mathrm{mg} / \mathrm{kg})$ và nghiệm thức bón NPK + PHC + NPISi $(5,46$ $\mathrm{mg} / \mathrm{kg}$ ), đồng thời hai nghiệm thức không bón chế phẩm vi sinh này không khác biệt ý nghĩa thống kê khi so sánh với nhau $(\mathrm{p}>0,05)$. Bên cạnh đó, có thể thấy nghiệm thức bón NPK + PHC + NPISi có hàm lượng $\mathrm{P}$ dễ tiêu cao nhất và khác biệt ý nghĩa thống kê so với 3 nghiệm thức còn lại $(\mathrm{p}<0,05)$. Điều này cho thấy bản thân phân hữu cơ đã có chứa một lượng lân hữu dụng nên khi kết hợp với việc bón chế phẩm vi sinh chịu mặn NPISi có chứa vi khuẩn hòa tan lân giúp lượng lân hữu dụng trong đất cuối vụ tăng lên đáng kể và khác biệt so với nghiệm thức bón chế phẩm vi sinh hoặc phân hữu cơ đơn lẻ. Trong khi đó, hàm lượng $\mathrm{K}$ trao đổi trong đất cuối vụ giữa các nghiệm thức dao động từ $1,97-1,99$ meq $/ \mathrm{kg}$ đất và 
khác biệt không có ý nghĩa thống kê giữa các nghiệm thức $(\mathrm{p}>0,05)$.

\subsubsection{Mật số vi sinh vật trong đất cuối vu}

Kết quả phân tích mật số vi sinh vật trong mẫu đất cuối vụ được trình bày trong Bảng 5 . Nhìn chung, có sự khác biệt ý nghĩa thống kê ở mức 5\% ( $\mathrm{p}<0,05)$ về mật số vi khuẩn, mật số nấm, mật số vi khuẩn cố định đạm, mật số vi khuẩn hòa tan lân và mật số vi khuẩn hòa tan silic trong đất $(\mathrm{p}<0,05)$, tuy nhiên mật số xạ khuẩn trong đất giữa các nghiệm thức không khác biệt ý nghĩa thống kê $(p>0,05)$ khi so sánh với nhau.
Cụ thể mật số vi khuẩn của các nghiệm thức thí nghiệm dao động 5,49-5,95 $\log _{10}(\mathrm{CFU} / \mathrm{g})$, trong đó nghiệm thức chỉ bón phân NPK có mật số vi khuẩn thấp nhất với giá trị $5,49 \log _{10}(\mathrm{CFU} / \mathrm{g})$, thấp hơn và khác biệt ý nghĩa thống kê so với nghiệm thức bón $\mathrm{NPK}+\mathrm{NPISi}\left(5,88 \log _{10}(\mathrm{CFU} / \mathrm{g})\right)$ và nghiệm thức bón NPK + PHC + NPISi $\left(5,95 \log _{10}(\mathrm{CFU} / \mathrm{g})\right.$, tuy nhiên, khác biệt không có ý nghĩa thống kê so sánh với nghiệm thức bón phân NPK + phân hữu cơ $(5,56$ $\left.\log _{10}(\mathrm{CFU} / \mathrm{g})\right)$. Ngoài ra, hai nghiệm thức bón chế phẩm vi sinh chịu mặn NPISi không khác biệt thống kê $(\mathrm{p}>0,05)$ khi so sánh với nhau về mật số vi khuẩn đất.

Bảng 5. Mật số vi sinh vật đất cuối vụ của các nghiệm thức thí nghiệm trên nền đất nhiễm mặn mô hình lúa tôm tại huyện Phước Long, tỉnh Bạc Liêu (01/2021)

\begin{tabular}{lrrrrrr}
\hline \multirow{2}{*}{ Nghiệm thức } & \multicolumn{7}{c}{ Log mật số $\left(\log _{\mathbf{1 0}}(\mathbf{C F U} / \mathbf{g})\right)$} \\
\cline { 2 - 7 } & Vi khuẩn & Nấm & Xạ khuẩn & $\begin{array}{c}\text { VK cố } \\
\text { định đạm }\end{array}$ & $\begin{array}{c}\text { VK hòa } \\
\text { tan lân }\end{array}$ & $\begin{array}{c}\text { VK hòa } \\
\text { tan silic }\end{array}$ \\
\hline $\mathrm{NPK}$ & $5,49^{\mathrm{b}}$ & $3,22^{\mathrm{b}}$ & 4,47 & $3,64^{\mathrm{b}}$ & $3,76^{\mathrm{b}}$ & $2,57^{\mathrm{c}}$ \\
$\mathrm{NPK}+\mathrm{NPISi}$ & $5,88^{\mathrm{a}}$ & $3,24^{\mathrm{b}}$ & 4,46 & $3,90^{\mathrm{a}}$ & $4,40^{\mathrm{a}}$ & $3,50^{\mathrm{a}}$ \\
$\mathrm{NPK}+\mathrm{PHC}$ & $5,56^{\mathrm{b}}$ & $3,31^{\mathrm{a}}$ & 4,48 & $3,70^{\mathrm{b}}$ & $3,78^{\mathrm{b}}$ & $3,22^{\mathrm{b}}$ \\
$\mathrm{NPK}+\mathrm{PHC}+\mathrm{NPSi}$ & $5,95^{\mathrm{a}}$ & $3,32^{\mathrm{a}}$ & 4,48 & $3,95^{\mathrm{a}}$ & $4,43^{\mathrm{a}}$ & $3,59^{\mathrm{a}}$ \\
\hline $\mathrm{F}$ & $*$ & $*$ & $\mathrm{~ns}$ & $*$ & $*$ & $*$ \\
$\mathrm{CV}(\%)$ & 3,63 & 1,56 & 1,02 & 3,65 & 8,17 & 12,86 \\
\hline
\end{tabular}

*Ghi chú: NPK: bón phân NPK theo công thức khuyến cáo, NPISi: chế phẩm vi sinh, PHC: phân hũu co: VK: vi khuẩn,

* là khác biệt ý nghĩa thống kê ở giữa các nghiệm thức ở mức ý nghĩa 5\% theo phép thủ Tukey và trong cùng một cột các số có chũ theo sau giống nhau thi không khác biệt ý nghĩa thống kê ở 5\%; ns: không khác biệt thống kê

Mật số nấm của các nghiệm thức thí nghiệm dao động trong khoảng từ 3,22 đến $3,32 \log _{10}(\mathrm{CFU} / \mathrm{g})$. Hai nghiệm thức có sử dụng phân hữu cơ gồm nghiệm thức bón NPK +2 tấn.ha ${ }^{-1}$ phân hữu cơ và nghiệm thức bón NPK + phân hữu cơ + chế phẩm vi sinh chịu mặn NPISi có mật số nấm cao nhất, lần lượt đạt $3,31 \log _{10}(\mathrm{CFU} / \mathrm{g})$ và $3,32 \log _{10}(\mathrm{CFU} / \mathrm{g})$, và khác biệt ý nghĩa thống kê $(\mathrm{p}<0,05)$ khi so sánh với hai nghiệm thức không sử dụng phân hữu cơ $(\mathrm{p}<0,05)$ gồm nghiệm thức đối chứng chỉ bón phân NPK $\left(3,22 \log _{10}(\mathrm{CFU} / \mathrm{g})\right.$ và nghiệm thức bón NPK + chế phẩm vi sinh chịu mặn NPISi $\left(3,24 \log _{10}\right.$ $(\mathrm{CFU} / \mathrm{g})$, tuy nhiên hai nghiệm thức bón phân hữu cơ này khác biệt không có ý nghĩa thống kê khi so sánh với nhau $(\mathrm{p}>0,05)$. Tương tự, hai nghiệm thức không bón phân hữu cơ còn lại cũng không khác biệt ý nghĩa thống kê $(\mathrm{p}>0,05)$ khi so sánh với nhau. Điều này có thể là do trong phân hữu cơ sông Gianh được sử dụng trong thí nghiệm này có chứa nấm Aspergillus sp. với mật số lên đến $10^{6} \mathrm{CFU} / \mathrm{g}$ phân bón đã giúp cải thiện đáng kể mật số nấm trong đất.

Mật số vi khuẩn cố định đạm, vi khuẩn hòa tan lân và vi khuẩn hòa tan silic trong đất cuối vụ lần lượt dao động trong khoảng 3,64-3,95, 3,76-4,43 và
2,57-3,59 $\log _{10}(\mathrm{CFU} / \mathrm{g})$. Nhìn chung, có cùng xu hướng về mật số vi khuẩn cố định đạm, hòa tan lân và hòa tan $\mathrm{Si}$ đó là mật số của chúng cao và khác biệt ý nghĩa thống kê $(p<0,05)$ ở hai nghiệm thức có bón chế phẩm vi sinh chịu mặn NPISi so với 2 nghiệm thức không bón chế phẩm vi sinh chịu mặn NPISi. Nghiệm thức bón phân NPK + PHC + NPISi có mật số vi khuẩn cố định đạm, hòa tan lân và hòa tan $\mathrm{Si}$ lần lượt là $3,95,4,43$ và $3,59 \log _{10}(\mathrm{CFU} / \mathrm{g})$, cao nhất và khác biệt ý nghĩa thống kê $(\mathrm{p}<0,05)$ khi so sánh với 2 nghiệm thức không bón chế phẩm vi sinh chịu mặn NPISi, đồng thời khác biệt không có ý nghĩa thống kê $(\mathrm{p}>0,05)$ khi so sánh với nghiệm thức bón phân NPK + NPISi. Nghiệm thức này có mật số vi khuẩn cố định đạm, hòa tan lân và hòa tan Si lần lượt đạt $3,90,4,40$ và $3,50 \log _{10}(\mathrm{CFU} / \mathrm{g})$. Trong khi đó, mật số vi khuẩn cố định đạm, vi khuẩn hòa tan lân và vi khuẩn hòa tan $\mathrm{Si}$ ở nghiệm thức đối chứng chỉ bón phân NPK đạt giá trị lần lượt là 3,64 , 3,76 và $2,57 \log _{10}(\mathrm{CFU} / \mathrm{g})$ và thấp nhất khi so sánh với các nghiệm thức thí nghiệm còn lại. Bên cạnh đó, nghiệm thức bón phân NPK + phân hữu cơ có mật số vi khuẩn cố định đạm, hòa tan lân và hoàn tan Si đạt giá trị lần lượt là $3,70,3,78$ và $3,22 \log _{10}$ $(\mathrm{CFU} / \mathrm{g})$. Đặc biệt ở nghiệm thức bón phân NPK + 
PHC cho mật số vi khuẩn hòa tan Si cao hơn và khác biệt ý nghĩa thống kê $(\mathrm{p}<0,05)$ khi so sánh với nghiệm thức đối chứng chỉ bón phân NPK. Trong khi đó chỉ, tiêu về mật số vi khuẩn cố định đạm và hòa tan lân thì không khác biệt ý nghĩa thống kê $(\mathrm{p}<0,05)$ giữa hai nghiệm thức này. Điều này có thể là do vi khuẩn hòa tan lân và cố định đạm trong phân hữu cơ bón không thể sống sót được vì không phải là vi khuẩn chịu mặn khi được đưa vào trong đất nhiễm mặn; hoặc cũng có thể trong phân hữu cơ có chứa vi khuẩn hòa tan Si có khả năng chịu được mặn và sau khi được bón vào đất nhiễm mặn vi khuẩn hòa tan $\mathrm{Si}$ đã sống sót và phát triển tốt mật số nên dẫn đến mật số vi khuẩn hòa tan Si ở nghiệm thức bón phân hữu cơ cao hơn so với nghiệm thức đối chứng.

\subsubsection{Hệ số tuơng quan và hồi quy}

Kết quả phân tích tương quan giữa mật số vi sinh vật với các chỉ tiêu về năng suất lúa, lượng dinh dưỡng hấp thu trong sinh khối thân lúa và dinh dưỡng trong đất được trình bày trong Bảng 6 cho thấy mật số vi khuẩn, mật số vi khuẩn cố định đạm, mật số vi khuẩn hòa tan lân và mật số vi khuẩn hòa tan silic có tương quan thuận ở mức rất cao và khác biệt ý nghĩa thống kê $(\mathrm{p}<0,05)$ với năng suất lúa, hàm lượng dinh dưỡng trong đất và trong thân lúa và hệ số tương quan dao động từ 0,52-0,99.

Bảng 6. Tương quan giữa năng suất lúa thực tế với mật số vi sinh vật trong đất cuối vụ và một số chỉ tiêu về hàm lượng dinh dưỡng trong thân lá lúa và trong đất

\begin{tabular}{|c|c|c|c|c|c|c|c|c|c|c|}
\hline & NSTT & $\mathbf{S i}_{\mathrm{ts}-\mathrm{T}}$ & $N_{t s}-T$ & $P_{t_{s}-T}$ & $K_{\mathrm{ts}}-\mathbf{T}$ & $\mathbf{S i}_{\mathbf{h t}-\boldsymbol{I}}$ & $\mathrm{NH}_{4}{ }^{+}$-Ð & $\mathrm{NO}_{3}^{-}-\mathrm{O}$ & $\mathbf{P}_{\mathrm{dt}-}-\mathrm{I}$ & $K_{t d \mathbf{d}}-\oplus$ \\
\hline MSVK & $0,88^{* *}$ & $0,81 * *$ & $0,82 * *$ & $0,52 * *$ & $0,68 * *$ & $0,74 * *$ & $0,95 * *$ & $0,96^{* *}$ & $0,82 * *$ & $0,04^{\mathrm{nc}}$ \\
\hline MSN & $0,34^{\mathrm{nc}}$ & $0,44^{\mathrm{nc}}$ & $0,48^{\mathrm{nc}}$ & $0,47^{\mathrm{nc}}$ & $0,80 * *$ & $0,56^{\mathrm{nc}}$ & $0,47^{\text {nc }}$ & $0,15^{\mathrm{nc}}$ & $0,46^{\mathrm{nc}}$ & $0,20^{\mathrm{nc}}$ \\
\hline MSVK-CĐÐ & $0,84 * *$ & $0,67 * *$ & $0,83 * *$ & $0,53 * *$ & $0,68 * *$ & $0,67 * *$ & $0,90 * *$ & $0,93 * *$ & $0,77 * *$ & $0,17^{\mathrm{nc}}$ \\
\hline MSVK-HTL & $0,86^{* *}$ & $0,77 * *$ & $0,78 * *$ & $0,82 * *$ & $0,59 * *$ & $0,68^{\mathrm{nc}}$ & $0,92 * *$ & $0,99 * *$ & $0,77 * *$ & $0,09^{\text {nc }}$ \\
\hline MSVK-HTSi & $0,74 * *$ & $0,80 * *$ & $0,86^{* *}$ & $0,75^{* *}$ & $0,87 * *$ & $0,85 * *$ & $0,90 * *$ & $0,82 * *$ & $0,65^{* *}$ & $0,06^{\mathrm{nc}}$ \\
\hline $\mathrm{Si}_{\mathrm{ts}}-\mathrm{T}$ & $0,70^{* *}$ & - & - & - & - & - & - & - & - & - \\
\hline $\mathrm{N}_{\mathrm{ts}}-\mathrm{T}$ & $0,72 * *$ & - & - & - & - & - & - & - & - & - \\
\hline $\mathrm{P}_{\mathrm{ts}} \mathrm{T}$ & $0,58 * *$ & - & - & - & - & - & - & - & - & - \\
\hline $\mathrm{K}_{\mathrm{ts}}-\mathrm{T}$ & $0,69 * *$ & - & - & - & - & - & - & - & - & - \\
\hline $\mathrm{Si}_{\mathrm{ht}}-\bigoplus$ & $0,72 * *$ & - & - & - & - & - & - & - & - & - \\
\hline $\mathrm{NH}_{4}{ }^{+}$-Đ & $0,87 * *$ & - & - & - & - & - & - & - & - & - \\
\hline $\mathrm{NO}_{3}{ }^{-}-\mathrm{D}$ & $0,83 * *$ & - & - & - & - & - & - & - & - & - \\
\hline $\mathrm{P}_{\mathrm{dt}}-\mathrm{Ð}$ & $0,86^{* *}$ & 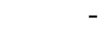 & - & - & - & - & - & - & - & - \\
\hline $\mathrm{K}_{\mathrm{td}}-\mathrm{Ð}$ & $0,02^{\mathrm{nc}}$ & - & - & - & - & - & - & - & - & - \\
\hline
\end{tabular}

*Ghi chú: **: tưong quan có ý nghĩa thống kê ở mức 1\%, nc: non correlation (không tuoong quan), NSTT: năng suất thực tế, Sits-T: Si tông số trong thân lúa, $N_{t s}-T$ : đạm tổng số trong thân lúa, $P_{t s-}-T$ : lân tổng số trong thân lúa, $K_{t s}-T: K$ tổng số trong thân lúa, $\mathrm{Si}_{h t}-\bigoplus$ : Si hòa tan trong đất, $\mathrm{NH}_{4}{ }^{+}-\bigoplus$ : $\mathrm{NH}^{+}$trong đất, $\mathrm{NO}_{3}-\bigoplus$ : $\mathrm{NO}_{3}{ }^{-}$trong đất, $P_{d t}$ - : lân dễ tiêu

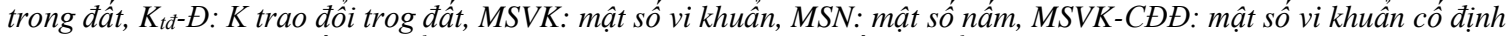
đạm, MSVK-HTL: mật số vi khuẩn hòa tan lân, MSVK-HTSi: mật số vi khuẩn hòa tan silic

Trong đó, năng suất thực tế có tương quan thuận và chặt chẽ với mật số vi khuẩn, mật số vi khuẩn cố định đạm, mật số vi khuẩn hòa tan lân với hệ số tương quan ở mức rất cao lần lượt là $0,88,0,84$ và 0,86 . Ngoài ra, năng suất lúa còn tương quan thuận với hàm lượng $\mathrm{Si}$ tổng số, đạm tổng số, lân và kali tổng số trong thân lúa với hệ số tương quan lần lượt là $0,70,0,72,0,58$ và 0,69 . Đặc biệt, năng suất lúa tương quan thuận ở mức chặt với hàm lượng dinh dưỡng trong đất gồm lượng $\mathrm{Si}$ hòa tan trong đất, $\mathrm{NH}_{4}{ }^{+}, \mathrm{NO}_{3}^{-}$và lân hữu dụng trong đất với hệ số tương quan lần lượt là $0,72,0,87,0,83$, và 0,86 , tuy nhiên năng suất lúa không tương quan với hàm lượng $\mathrm{K}_{\mathrm{td}}$ trong đất.

Bên cạnh đó, mật số vi khuẩn còn tương quan thuận ở mức rất chặt với các chỉ tiêu silic tổng số trong thân $(0,88)$, đạm tổng số trong thân $(0,82)$,
$\mathrm{NH}_{4}{ }^{+}(0,95), \mathrm{NO}_{3}^{-}(0,96)$ và lân dễ tiêu trong đất $(0,82)$. Mật số vi khuẩn cố định đạm tương quan thuận và chặt với đạm tổng số trong thân, $\mathrm{NH}_{4}{ }^{+}$và $\mathrm{NO}_{3}{ }^{-}$trong đất với hệ số tương quan lần lượt là 0,83 , 0,90 và 0,93 . Mật số vi khuẩn hòa tan lân tương quan chặt với hàm lượng lân tổng số trong thân $(0,82)$, $\mathrm{NH}_{4}^{+}(0,92), \mathrm{NO}_{3}^{-}(0,99)$ và hàm lượng lân dễ tiêu (hữu dụng) trong đất $(0,77)$. Mật số vi khuẩn hòa tan Si tương quan chặt với hàm lượng $\mathrm{Si}$ tổng số trong thân, đạm tổng số trong thân, kali tổng số trong thân, Si hòa tan trong đất, $\mathrm{NH}_{4}{ }^{+}$và $\mathrm{NO}_{3}{ }^{-}$trong đất với hệ số tương quan lần lượt là $0,80,0,86,0,87,0,85,0,90$ và 0,82 . Trong khi đó, mật số nấm $\mathrm{K}$ trao đồi trong đất không tương quan với hầu hết các chỉ tiêu đánh giá.

Tóm lại, mật số vi khuẩn, mật số vi khuẩn cố định đạm, mật số vi khuẩn hòa tan lân, và mật số vi 
khuẩn hòa tan silic là những yếu tố chính giúp gia tăng năng suất lúa thông qua việc cố định đạm từ khí trời, hòa tan lân và silic khó tan thành dạng dễ tiêu nhằm giúp cho cây lúa có thể hấp thu và huy động một cách hiệu quả cao trong thân lá, từ đó gia tăng khả năng tăng trưởng, sức chống chịu và làm tăng năng suất lúa. Kết quả này tương đồng với nhiều nghiên cứu trước đây cho thấy việc bồ sung các nhóm vi khuẩn có chức năng cố định đạm, hòa tan lân, hòa tan silic giúp thúc đầy quá trình sinh trưởng, từ đó gia tăng năng suất lúa (Ahmed et al., 2008; Kundu \& Guar, 1984; Trần Võ Hải Đường và ctv., 2020).

\section{KẾT LUẬN}

Sử dụng chế phẩm vi sinh chịu mặn NPISi chứa các dòng vi khuẩn có chức năng cố định đạm, hòa tan lân, tổng hợp IAA và hòa tan Si trên nền phân bón NPK theo khuyến cáo cho cây lúa trên nền đất nhiễm mặn trong mô hình canh tác lúa tôm tại huyện Phước Long, tỉnh Bạc Liêu giúp gia tăng sinh trưởng, năng suất lúa và cải thiện một số chỉ tiêu về đặc tính đất như hàm lượng $\mathrm{Si}$ hữu dụng, $\mathrm{NH}_{4}{ }^{+}, \mathrm{NO}_{3}{ }^{-}$ và $\mathrm{P}$ dễ tiêu trong đất, gia tăng mật số vi khuẩn có lợi trong đất, đồng thời giúp gia tăng hàm lượng đạm, lân, kali và Si hấp thu trong thân lúa. Do đó, tiềm năng sử dụng chế phẩm vi sinh chịu mặn NPISi cho đất trồng lúa trên nền đất nhiễm mặn giúp bảo vệ cây lúa và năng suất là rất cao.

\section{TÀI LIỆU THAM KHẢO}

Ahmed, A. H. H., Harb, E. M., Higazy M. A., \& Morgan, S. H. (2008). Effect of silicon and boron foliar applications on wheat plants grown under saline soil conditions. Int. J. Agric. Res., 3(1), 126. https://doi.org/10.3923/ijar.2008.1.26

Bashan, Y., Moreno, M., \& Troyo, E. (2000). Growth promotion of the seawaterirrigated oilseed halophyte Salicornia bigelovii inoculated with mangrove rhizosphere bacteria and halotolerant Azospirillum spp. Biology and Fertility of Soils, 32, 265-272. https://doi.org/10.1007/s003740000246

Bashan, Y. (1998). Inoculants of plant growthpromoting bacteria for use in agriculture. Biotechno Advances, 16(4), 729-770. https://doi.org/10.1016/S0734-9750(98)00003-2

Cordovilla, M. P., Ligero, F., \& Lluch, C. (1994). The effect of salinity on nitrogen fixation and assimilatin in Vicia faba. Journal of Experimental Botany, 45(10), 1483-1488. https://doi.org/10.1093/jxb/45.10.1483

Dodd, I. C., \& Perez, F., (2012). Microbial alleviation of crop salinity. Journal of
Experimental Botany, 63, 3415-3428.

https://doi.org/10.1093/jxb/ers033

Gisbert, C., Rus, A. M., Bolarin, M. C., Lopez, J. M., Arrillaga, I., Montesinos, C., Caro, M., Serrano, R. \& Moreno V. (2000). The yeast HALI gene improves salt tolerance of transgenic tomato. Plant Physiol, 123, 393-402. https://doi.org/10.1104/pp.123.1.393

Hallmark, C. T., Wilding, L. P., \& Smeck (1982). Chemical and Microbiological Properties. In: A.L. Page (Eds). Methods of Soil Analysis (pp. 263-274). Madison.

Kundu, B. S., \& Gaur, A. C. (1984). Rice response to inoculation with $\mathrm{N} 2$ fixing and P-solubilizing microorganisms. Plant and Soil, 79, 227-234. https://doi.org/10.1007/BF02182344

Lâm Thị Bạch Vân. (2008). Đánh giá khả năng cố định đạm của dòng vi sinh vật bản địa lên đặc tính sinh trương và năng suất của cây lúa trên đất phèn nhẹ (luận văn tốt nghiệp thạc sĩ). Trường Đại học Cần Thơ.

Lê Văn Tiến, Quan Thị Ái Liên \& Võ Công Thành. (2011). Kết quả chọn dòng giống lúa Một Bụi Đỏ có chất lượng tốt tại nhà lưới Trường Đại học Cần Thơ. Tạp chi Khoa học Trưòng Đại hoc Cần Tho, 18, 157-162.

Malinovskaya, I. M., Kosenko, V., Votselko, S. K., \& Podgorskii, V. S. (1990). Role of Bacillus mucilagenosis polysaccharide in degradation of silicate minerals. Mikrobiologiya, 59, 70-78.

Mehta, S. \& Nautiya, C. S. (2001). An efficient method for qualitative screening of phosphatesolubilizing bacteria. Current Microbiology, 43, 51-56. https://doi.org/10.1007/s002840010259

Nguyễn Khởi Nghĩa \& Nguyễn Thị Kiều Oanh. (2017). Tuyển chọn chất mang và chất nền sản xuất chế phẩm vi sinh chứa ba dòng vi khuẩn chịu mặn kích thích sinh trưởng cây trồng (Burkholderia cepacia BL1-10, Bacillus megaterium ST2-9 và Bacillus aquimaris KG63). Tạp chí Công nghệ Sinh học, 15(2), 381-392.

Nguyễn Ngọc Nga. (2008). Anh hưởng của vi khuẩn cố định đạm và vi khuẩn hòa tan lân lên năng suất cây lúa ở huyện Bình Minh, tỉnh Vĩnh Long (luận văn tốt nghiệp thạc sĩ). Trường Đại học Cần Thơ.

Otsuki, A., \& Sekiguchi, K. (1983). Automated determination of ammonium in natural freshwater using salicylate-hexacyanoferratedichloroisocyanurate system. Analytical letters, 16(A13), 979-985. https://doi.org/10.1080/00032718308067955

Park, M., Kim, C., Yang, J., Lee, H., Shin, W. \& Kim, S. (2005). Isolation and characterization of diazotrophic growth promoting bacteria from rhizosphere of agricultural crops of Korea. 
Microbiological Research, 160, 127-133. https://doi.org/10.1016/j.micres.2004.10.003

Pepper, I. L., \& Gerba, C. P. (2004). Environmental Microbiology: A laboratory manual (2nd ed). Elsevier Academic Press.

Pereira, H. S., Korndorfer, G. H., Moura, W. F., \& Correa, G. F. (2003). Silicon extractors available in slag and fertilizer. Rev. Bras. Ciênc. Solo., 27(2), 265-274. https://doi.org/10.1590/S010006832003000200007

Puente, M. E., Holguin, G., Glick, B. R. \& Bashan, Y. (1999). Root surface colonization of balck mangrove seedlings by Azospirillum halopraeferens and Azospirillum brasilense in seawater. FEMS Microbiol. Ecol., 29, 283-292.. https://doi.org/10.1111/j.15746941.1999.tb00619.x

Reinhold, B., Hurek, T., Fendrik, I., Pot, B., Gillis, M., Kersters, K., \& Thielemans, S., D. L. (1987). Azospirillum halopraeferens sp. no., a nitrogen fixing organism associated with roots of Kallar grass (Leptochloa fusca (L.) Kunth.). International Journal of Systematic and Evolutionary Microbiology, 37(1), 43-51. https://doi.org/10.1099/00207713-37-1-43

Rodrigues, F. A., \& Datnoff, L. E. (2005). Silicon and rice disease management. Fitopatol. Bras. 30, 457-469. https://doi.org/10.1590/S010041582005000500001

Sims, J. T. (2000). Soil test phosphorus: Bray and Kurtz P-1. In: G. Pierzynski (Eds.), Methods of Phosphorus Analysis for Soils, Sediments, Residuals, and Waters (pp. 13-14). North Carolina State University.

SIWRMP. (1995). Major Issues in Water Resources Development in the Mekong Delta. Report of the Sub-Institute of Water Resources Management and Planning, HCM city.
Sumner, M. E., \& Miller, W. P. (1996). Cation exchange capacity, and exchange coefficients. In: D. L. Sparks (ed.) Methods of soil analysis. Part 2: Chemical properties (3rd ed). Madison.

Trần Thị Hồng Nhung. (2010). Phân lập và nhận diện các dòng vi khuẩn có khả năng hòa tan lân và kali trong đất của núi đá vôi ở Kiên Giang (luận văn tốt nghiệp thạc sĩ). Trường Đại học Cần Thơ.

Trần Võ Hải Đường \& Nguyễn Khởi Nghĩa. (2018). Phân lập và tuyển chọn vi khuẩn hòa tan silic từ nhiều môi trường sống khác nhau. Tạp chi Khoa hoc và Công nghệ Truờng Đại học Thái Nguyên, 180(4), 9-14.

Trần Võ Hải Đường \& Nguyễn Khởi Nghĩa. (2020). Hiệu quả của 5 dòng vi khuẩn hòa tan silic lên sinh trưởng và năng suất lúa một bụi đỏ trên nền đất nhiễm mặn trong mô hình canh tác lúa-tôm tại huyện Phước Long, tinh Bạc Liêu. Tạp chí Khoa hoc Truòng Đại hoc Cần Tho, 56, 47-57. https://doi.org/10.22144/ctu.jsi.2020.068

Trung tâm Khuyến nông tỉnh Bạc Liêu (2017, ngày 24 tháng 5). Kỹ thuật canh tác tôm-lúa. https://ttknbaclieu.gov.vn/ThucDon/BanTin/Ban TinXem/

Venkateswarlu, B., \& Shanker, A. K. (2009). Climate change and agriculture: adaptation and mitigation strategies. Indian J. Agron, 54, 226-230.

Wei-min, D., Ke-qin, Z. Bin-wu, D., Cheng-xiao, S., Kang-le, Z., Run, C., \& Jie-yun, Z. (2005). Rapid determination of silicon content in rice. Rice Science, 12(2), 145-147.

Wilson, P. W., \& Knight, S. G. (1952). Experiments in Bacterial Physiology. Burgess Publishing Co.

Yoshida, S. (1981). Fundamentals of rice crop science. IRRI, Philippines. 